\title{
Review Article \\ Seismic Behavior of Corroded RC Bridges: Review and Research Gaps
}

\author{
Kaveh Andisheh, Allan Scott, and Alessandro Palermo \\ Department of Civil Engineering, University of Canterbury, Private Bag 4800, Christchurch 8140, New Zealand \\ Correspondence should be addressed to Kaveh Andisheh; kavehandisheh@gmail.com
}

Received 20 November 2015; Accepted 7 April 2016

Academic Editor: Flavio Deflorian

Copyright (C) 2016 Kaveh Andisheh et al. This is an open access article distributed under the Creative Commons Attribution License, which permits unrestricted use, distribution, and reproduction in any medium, provided the original work is properly cited.

Chloride-induced corrosion and its effect on structural and seismic performance of reinforced concrete (RC) structures have been the topic of several research projects in past decades. This literature review summarizes the state of the art by presenting a brief description of chloride-induced corrosion, its main characteristics and influencing factors, a summary of experimental published data, and existing corrosion-induced deterioration models together with numerical and experimental methods used to evaluate corroded RC bridge pier. This literature review highlights the need for reliable deterioration models for RC structures and appropriate analysis methods are needed for design of new structures or assessment of existing civil engineering structures especially in seismic areas.

\section{Introduction}

In recent years, growing attention has been given to the effects of corrosion on the structural performance of reinforced concrete (RC) structures. According to National Association of Corrosion Engineers (NACE), the direct annual cost of corrosion of infrastructure was more than $\$ 22$ billion in the USA in 2002. American Society of Civil Engineers (ASCE) has reported that the USA should invest \$2.2 trillion over the next five years to repair and upgrade more than 300,000 bridges in the USA that are approaching the end of their design life [1]. While RC structures in pristine condition can be expected to satisfy the code requirements of a given era, corrosion of reinforcing steel affects the seismic performance of the structure over time. Therefore, old corroded RC structures become vulnerable to probable future earthquakes. It should be noted that there are two well-known forms of corrosion: carbonation-induced and chloride-induced corrosion. Carbonation-induced corrosion is defined as a chemical reaction between atmospheric carbon dioxide and the product of cement hydration, mainly calcium hydroxide [2]. Chloride-induced corrosion is defined as an electrochemical reaction between chloride product (such as
iron(II)-chloride) and water. In this paper, chloride-induced corrosion has been studied. The vast majority of deterioration in RC structures is a result of corrosion of reinforcing steel due to ingress of chloride ions from either deicing salts or marine environment. Corrosion changes effective characteristics and mechanical properties of materials, leading to possible degraded seismic performance of corroded RC structures. This problem is very critical for bridges and more importantly for bridge piers since they dissipate earthquake energy through the formation of plastic hinges. Corrosion is a time-dependent process. Therefore, lifetime analysis is needed to evaluate seismic and structural performance of corroded structures. Long-term seismic performance of RC structures subject to corrosion includes three main parts that are shown in Figure 1: (1) chloride-induced corrosion, (2) deterioration of RC structures or elements due to corrosion, and (3) lifetime (time-dependent) seismic analysis and performance of corroded RC bridge pier.

Figure 2 shows an overview of the aforementioned three main parts. Two critical phenomena are the reduction in cross section area of reinforcing steel and the formation of corrosion by-product, leading to cracking and spalling of concrete in RC structures. Hence, corrosion-induced 


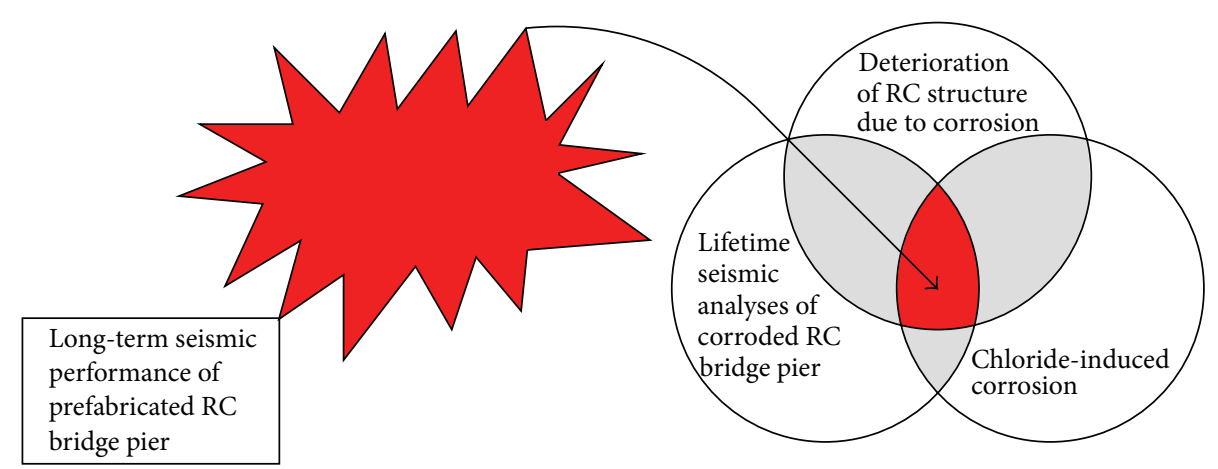

FIGURE 1: Outline of long-term seismic performance of corroded structures.

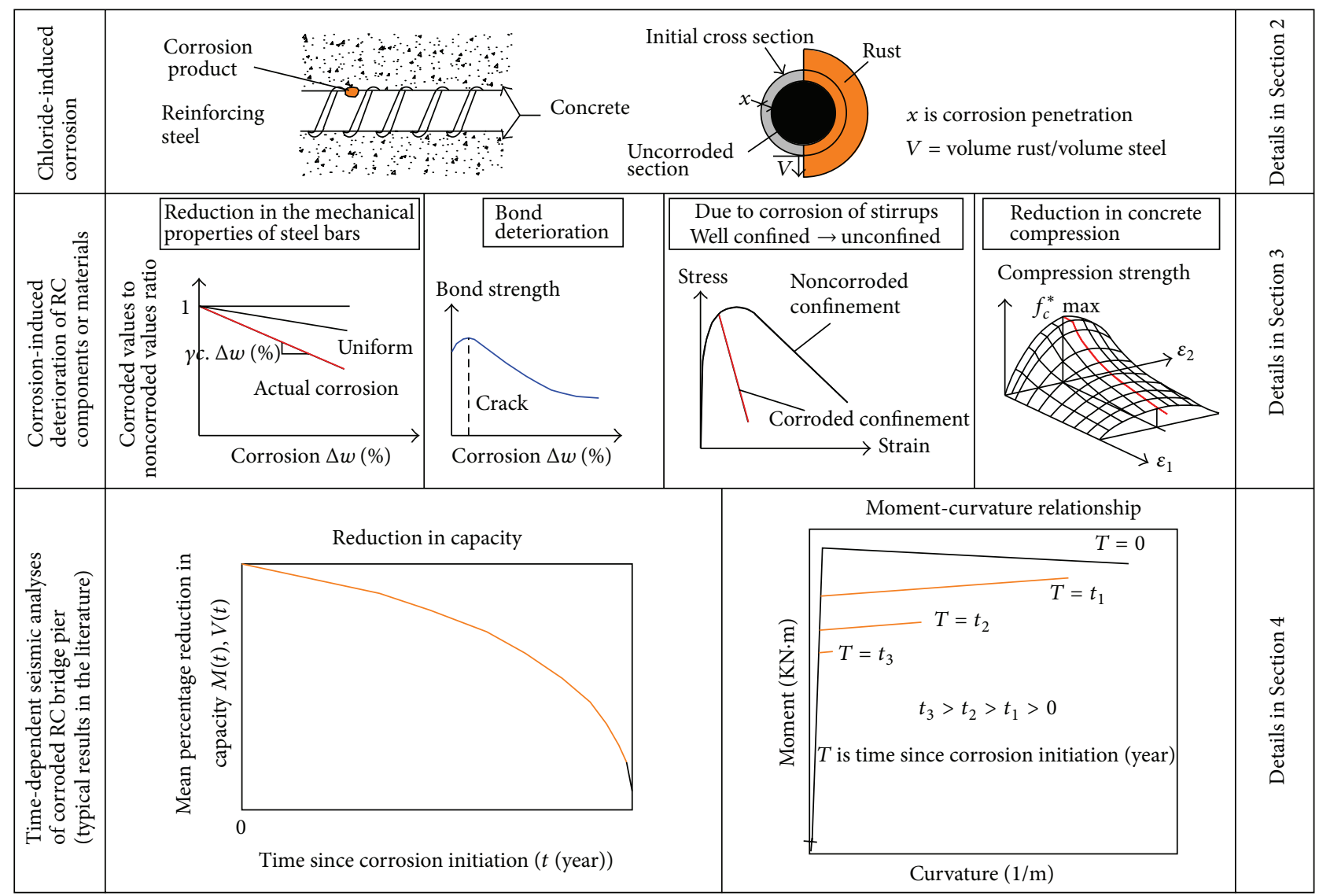

FIGURE 2: Overview of main parts of long-term seismic performance of corroded RC bridge pier.

deterioration of RC structures can be classified into four groups as follows:

(1) Reduction in mechanical properties of steel reinforcements.

(2) Deterioration of bond between steel and concrete.

(3) Degradation of confinement (decreasing shear strength).

(4) Damage to concrete material.

Traditional seismic analysis cannot be used for RC structures subjected to corrosion hazard for the following reasons. The first reason is that corrosion depends on time, so mechanical properties of structural elements are a function of time. The second reason is lack of robust analytical/numerical cyclic models to predict behavior of corroded RC structures subjected to earthquakes. Hence, lifetime analysis of corroded RC structures is needed, taking into consideration the corresponding deterioration models for corroded RC structures, amount of corrosion, and important factors influencing corrosion process such as corrosion initiation time. Figure 3 illustrated force-displacement response of a corroded bridge pier over time. The outcomes of lifetime seismic analysis of corroded RC structures can be represented in terms of 


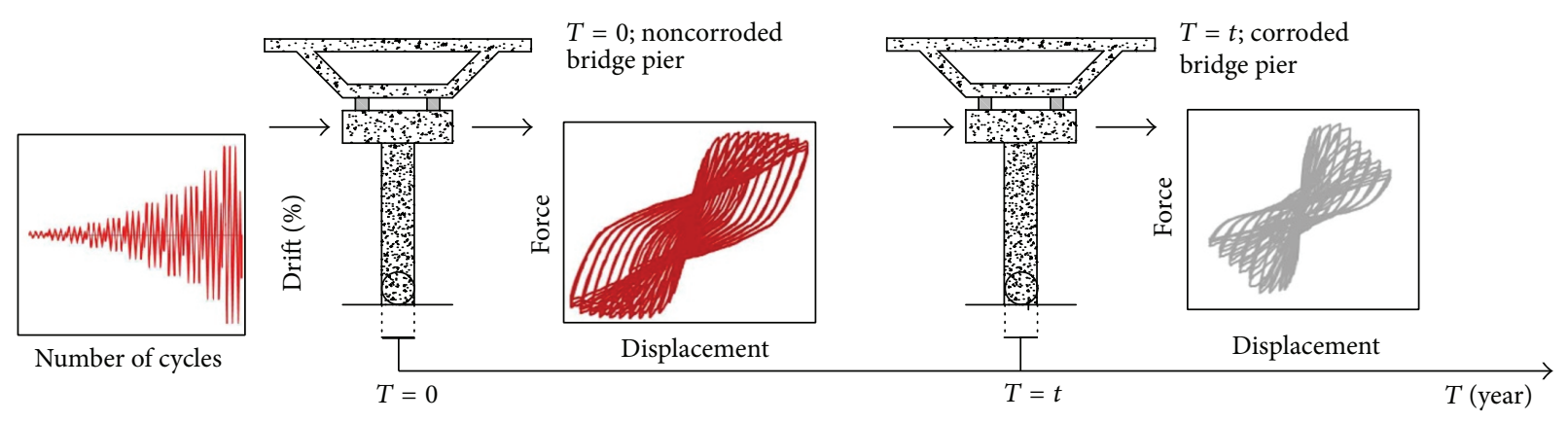

FiguRE 3: Force-displacement response of a corroded bridge pier over time.

reduction in structural capacity or increase in probability of failure over time.

This paper summarizes the state of the art by presenting a brief description of chloride-induced corrosion, its main characteristics and influencing factors, a summary of experimental published data, and existing corrosion-induced deterioration models together with numerical and experimental methods used to evaluate corroded RC bridge pier. The main objective of this paper is highlighting research gaps and critical need to further studies in this field.

\section{Chloride-Induced Corrosion}

Corrosion of reinforcing steel embedded in concrete is an electrochemical process. The process is initiated as soon as aggressive ions such as chloride penetrate the concrete cover and reach the steel reinforcement. Once the corrosion process commences, not only does the cross-sectional area of the corroding reinforcing steel decrease but also corrosion byproducts such as rust are formed. The irregular loss of cross section leads to alterations in mechanical properties of reinforcing steels. The average volume of rust is approximately 2-4 times greater than that of the steel resulting in the development of tensile stresses in concrete, which ultimately lead to cracking and spalling of the cover concrete $[3,4]$. Moreover, bond between steel and concrete decreases. It should be noted that a low level of corrosion can result in a slight increase in bond strength, but increasing corrosion level leads to reduction in bond between concrete and steel reinforcement [5-10].

2.1. Chloride Content in Reinforced Concrete Structures: Initial Stage and Threshold Value. Chloride content is the amount of chloride ion at the surface of steel reinforcement. To initiate corrosion, it should reach a certain level called critical chloride content $\left(C_{\text {crit }}\right) . C_{\text {crit }}$ is a threshold value needed to propagate chloride ion. However, there is difference between the scientific and practical definitions of $C_{\text {crit }}$. In scientific definition, $C_{\text {crit }}$ is the threshold required to propagate on the surface of the steel, while in practical definition it is associated with the acceptable deterioration of reinforcing steel.

Angst et al. [11] have summarized the values of $C_{\text {crit }}$ experimentally measured from steel embedded in cement based material in laboratory condition, from real structures and from steel directly immersed in solution, reported by 32 published articles. The maximum and minimum values of $C_{\text {crit }}$ based on the review of aforementioned experimental results together with maximum allowable total $\mathrm{Cl}^{-} \%$ cement weight proposed by various ACI documents are presented in Table 1.

Moreover, Hussain et al. [12] estimated critical chloride of steel embedded in cement based material and showed that threshold of free $\mathrm{Cl}^{-}$, independent from $\mathrm{C}_{3} \mathrm{~A}$ content, varies from 0.22 to $0.29 \% \mathrm{cw}$ (cement weight), while threshold of total chloride, dependent on $\mathrm{C}_{3} \mathrm{~A}$ content, varies from 0.48 to $1.2 \% \mathrm{cw}$ for various amounts of $\mathrm{C}_{3} \mathrm{~A}$ content. The results agree with the associated range represented in Table 1 . Ann and Song [13] stated that measurement accuracy of $C_{\text {crit }}$ in terms of free $\mathrm{Cl}^{-}$and $\mathrm{Cl}^{-} / \mathrm{OH}^{-}$ratio is relatively low. Expressing $\mathrm{C}_{\text {crit }}$ in terms of total $\mathrm{Cl}^{-}$(\% cement weight) takes into consideration inhibiting effect of cement and the aggressive nature of chloride. Angst et al. [11] also have reported important factors influencing $C_{\text {crit }}$ based on reviewing 24 articles. The important factors influencing $C_{\text {crit }}$ have been categorized into three groups: steel type and condition, concrete and binder properties, and external factors. In addition to this, Alonso et al. [14] concluded that the type of steel does not significantly affect the critical chloride value, but after depassivation, the average rate of corrosion is slightly higher in ribbed bar. Glass and Buenfeld [15] showed that chloride binding reduced free chloride due to the removal of chloride ions from the pore solution of concrete. It also reduced total chloride content at depth. Maruya et al. [16] concluded that, because of condensation and ion absorption due to pore wall in wetting and drying cycles, increasing the cycle raises total chloride in RC structures. Polder [17] stated that, from a theoretical point of view, the effect of concrete resistivity on critical chloride value still remains unclear. Based on information above, the table presented by Angst et al. [11] has been updated. The update also includes additional new factors marked as “*”. Finally, Table 2 presents important factors influencing critical chloride content in terms of total $\mathrm{Cl}^{-}, \mathrm{Cl}^{-} / \mathrm{OH}^{-}$ratio, and free $\mathrm{Cl}^{-}$.

It is worth noting that Angst et al. [18] have developed a probabilistic model to investigate the effect of specimen size on $C_{\text {crit }}$ measured in laboratories. They have concluded that increasing sample's geometrical dimension decreases $C_{\text {crit }}$, but to apply this result to steel embedded in concrete it has to be verified through experimental studies. 


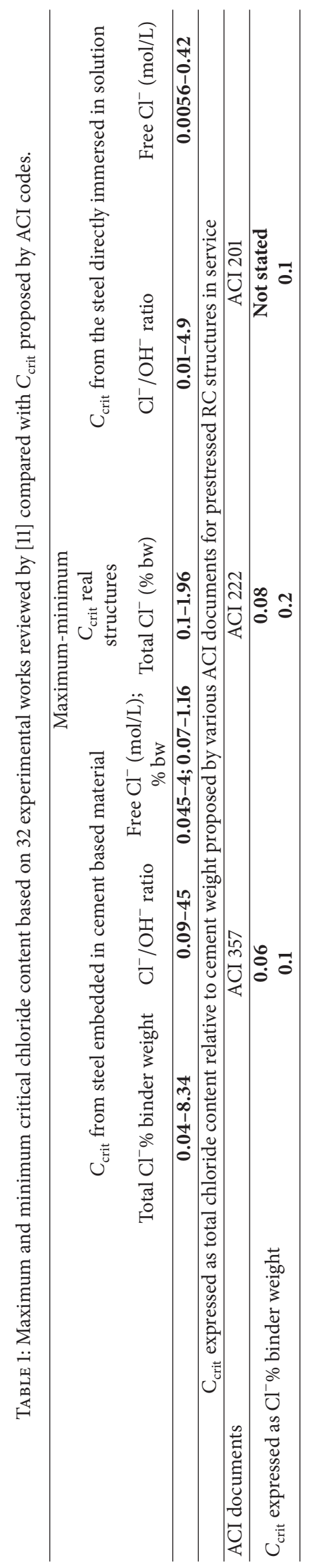


TABLE 2: Important factors and their effects on critical chloride content.

\begin{tabular}{|c|c|c|c|}
\hline \multirow{2}{*}{ Factor } & \multicolumn{3}{|c|}{ Effect on critical chloride content } \\
\hline & Total $\mathrm{Cl}^{-} \%$ cement weight & $\mathrm{Cl}^{-} / \mathrm{OH}^{-}$ratio & Free $\mathrm{Cl}^{-}$ \\
\hline \multicolumn{4}{|c|}{ Steel type and condition } \\
\hline Defect at steel-concrete interface & $\downarrow$ & $\downarrow$ & $\downarrow$ \\
\hline Polishing and sandblasting & $\uparrow$ & $\uparrow$ & $\uparrow$ \\
\hline Steel potential (>-200 mV SCE) & $\mathrm{O}$ & $\mathrm{O}$ & $\mathrm{O}$ \\
\hline Steel potential (<-200 mV SCE) & $\downarrow$ & $\downarrow$ & $\downarrow$ \\
\hline Steel type & $\mathrm{O}$ & $\mathrm{O}$ & $\mathrm{O}$ \\
\hline \multicolumn{4}{|c|}{ Concrete and binder properties } \\
\hline $\mathrm{w} / \mathrm{c}$ ratio & $\downarrow$ & $\downarrow$ & $\downarrow$ \\
\hline Chloride binding* & $\downarrow \uparrow$ & $\mathrm{O}$ & $\downarrow \mathrm{O}$ \\
\hline $\mathrm{pH}$ & $\uparrow$ & $\uparrow$ & $\uparrow$ \\
\hline Electrical resistivity* $^{*}$ & $\uparrow \mathrm{NC}$ & $\uparrow$ & $\uparrow$ \\
\hline Silica fume & $\downarrow$ & $\downarrow$ & $\downarrow$ \\
\hline Fly ash & $\downarrow \uparrow \mathrm{O}^{\mathrm{b}}$ & $\downarrow \mathrm{O}^{\mathrm{b}}$ & $\downarrow \mathrm{O}^{\mathrm{b}}$ \\
\hline GGBS (ground granulated blast furnace slag) & $\downarrow \uparrow \mathrm{O}^{\mathrm{b}}$ & $\mathrm{O}$ & $\mathrm{O}$ \\
\hline SRPC (low $\mathrm{C}_{3} \mathrm{~A}+\mathrm{C}_{4} \mathrm{AF}$ content) & $\downarrow$ & NS & NS \\
\hline \multicolumn{4}{|c|}{ External factors } \\
\hline Moisture in rather dry concrete & $\downarrow$ & $\downarrow$ & $\downarrow$ \\
\hline Moisture in nearly saturated concrete & $\uparrow$ & $\uparrow$ & $\uparrow$ \\
\hline Moisture variation & $\downarrow$ & $\downarrow$ & $\downarrow$ \\
\hline Oxygen availability & $\downarrow$ & $\downarrow$ & $\downarrow$ \\
\hline Temperature & $\downarrow$ & $\downarrow$ & $\downarrow$ \\
\hline Condensation in wet and drying cycle ${ }^{*}$ & $\uparrow$ & NS & NS \\
\hline
\end{tabular}

$\downarrow \uparrow$ indicates decreasing and increasing critical value with an increase of concerning factor; NS: result not stated; NC: the effect of the concerning factor is unclear; O: the concerning factor has no effect; b: contradicting results reported in the literature. SRPC: sulphate resistant Portland cement.

* indicates additional new factors if compared with the table presented by Angst et al. [11].

A number of methods for determining the total chloride content and the free chloride content are applied in practical applications. For measuring the total chloride content, drilled cores from hardened concrete are analyzed. The total chloride content in concrete powder-nitric acid solution can be measured by a number of methods such as titration, use of ion selective electrodes, or spectrophotometric methods. However, a more expensive but very accurate method is to determine the total chloride content in concrete powder using X-ray fluorescence spectrometry (XRF). To determine the free chloride content, pore solution expression, leaching techniques, and ion selective electrodes are used in the literature [11]. Further information can be found in [11] and its corresponding references.

2.2. Pitting Corrosion: Limit Step to Start Pitting Corrosion. It has been shown that the formation of macrocell, that is, small anodic area in comparison with large cathodic area, is observed in pitting (localized) corrosion [19-23]. It has been confirmed that three transitions occur in pitting corrosion: the first is transition from initiation stage to propagation stage, called depassivation [24]; the second is transition from depassivation to repassivation (the repassivation phase called metastable); and the third is transition from metastable to pit growth. As mentioned before, the first transition is related to existing critical chloride content. In metastable, nucleation occurs, also called repassivation, depending on chemistry or metallurgy condition. Then in case of maintaining aggressive chemical composition in pit cavity, the transition from nucleation to stable pit growth occurs. This transition is due to the simultaneous ingress of $\mathrm{H}^{+}$and $\mathrm{Cl}^{-}$and other anions into pit cavity [25-27]. Bertolini et al. [28] stated that pitting corrosion for reinforcement of steel in concrete is due to the acidification of pit cavity and ingress of $\mathrm{Cl}^{-}$ into the pit. Broomfield [29] found that steel reinforcement corrosion starts with the formation of a number of pits. Increasing the number of pits causes them to join up and form a general corrosion. Angst et al. [30] concluded that a transition from anodic to cathodic control occurs in pitting corrosion. However, it is not clear in which chloride content this transition takes place, so further investigation in this area should be carried out. It is clear that pitting corrosion occurs due to existence of high amount of chloride ion in a certain location. This means that corrosion potential is greater than pitting potential in that location [11]. Since pitting corrosion causes significant cross section loss in reinforcing steels, in structural analysis the amount of cross section loss due to pitting corrosion is a very important parameter. Therefore, researchers estimated a factor called "pitting factor" that is used to calculate pit depth and related loss of steel cross section. Pitting factor is the ratio of maximum pit depth on average corrosion penetration. Pitting factors reported 
TABLE 3: Pitting factors obtained from literature.

\begin{tabular}{|c|c|c|c|c|c|c|}
\hline Authors and date & $D_{(\mathrm{mm})}$ & $L_{(\mathrm{mm})}$ & Time (day) & $\begin{array}{c}\text { Number of } \\
\text { samples }\end{array}$ & $i_{\text {corr }}\left(\mu \mathrm{A} / \mathrm{cm}^{2}\right)$ & $\begin{array}{c}\text { Pitting factor: }(R) \\
\text { Mean; COV }\end{array}$ \\
\hline \multirow{2}{*}{ González et al. [73] } & 8 & 500 & 6 years & \multirow{2}{*}{ NS } & $0.1-7.0$ & $4.4-5.9 ; \mathrm{NS}$ \\
\hline & 16 & 400 & 30 & & $10-100$ & 5.9-16.1; NS \\
\hline Rodriguez et al. [74] & 6 & 650 & $100-200$ & 18 & 100 & $4-11.7 ; 0.05-0.22$ \\
\hline Rodriguez et al. [75] & 12 & 2300 & $100-200$ & 16 & 100 & $4.0 ; 0.15$ \\
\hline Torres-Acosta and Martínez-Madrid [31] & 13 & 310 & 700 & 35 & NS & $5.5 ; 0.59$ \\
\hline \multirow{7}{*}{ Stewart $[76]$} & 8 & \multirow{6}{*}{800} & \multirow{7}{*}{50 years } & & \multirow{7}{*}{1} & $7.00 ; 0.18$ \\
\hline & 16 & & & & & $7.68 ; 0.16$ \\
\hline & 24 & & & & & $8.08 ; 0.16$ \\
\hline & 28 & & & & & $8.23 ; 0.15$ \\
\hline & 32 & & & & & $8.36 ; 0.15$ \\
\hline & 36 & & & & & $8.48 ; 0.15$ \\
\hline & 10 & 100 & & & & $1.65 ; 0.22$ \\
\hline Cairns et al. [77] & 16 & NS & $100-400$ & 25 & $10-50$ & $23.8 ; 0.56$ \\
\hline Torres-Acosta et al. [78] & 10 & 1500 & $40,80,200$ & 8 & 80 & $11.7 ; \mathrm{NS}$ \\
\hline \multirow{2}{*}{ Stewart and Al-Harthy [79] } & 16 & \multirow{2}{*}{100} & \multirow{2}{*}{78} & \multirow{2}{*}{32} & $160-185$ & $6.20 ; 0.18$ \\
\hline & 27 & & & & $125-150$ & $7.10 ; 0.17$ \\
\hline
\end{tabular}

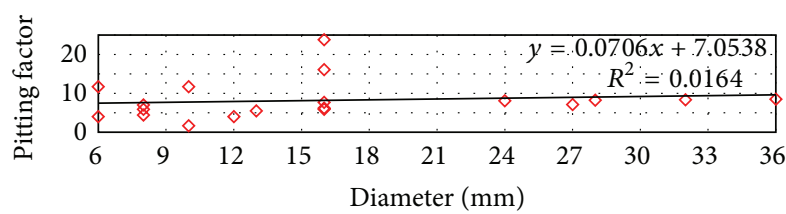

FIGURE 4: Pitting factor for different diameter sizes of bars regresses from results represented in Table 5 .

in the literature have been collected from 8 experimental investigations and are summarized in Table 3.

Figure 4 shows the relationship between diameter size of reinforcing steel and pitting factor regressed from the results represented in Table 5. According to this figure, pitting factor increases with the growth of diameter sizes of reinforcing steels.

Average corrosion penetration can be calculated based on mass loss due to corrosion and estimation of associated equivalent diameter of corroded bar [31]. It has been stated that pitting factor rises with increase of reinforcing steel bars diameter [32].

Using Faraday's law, assuming hemispherical form for pits, the maximum pit depth is as follows [33]:

$$
p(t)=0.0116 \times R \times i_{\text {corr }}(l) \times t
$$

where $p(t)$ is the maximum pit depth $(\mathrm{mm}), R$ is pitting factor, $i_{\text {corr }}(l)$ is corrosion current density $\left(\mu \mathrm{A} / \mathrm{cm}^{2}\right)$, and $t$ is time (year).

2.3. Predicting the Rate of Corrosion. Rate of corrosion and time of the commencement of corrosion are very important factors influencing the deterioration of RC structures as they are related to residual capacity of corroded structures. Many factors affect the corrosion rate which are classified into three groups: named steel condition, concrete and binder properties, and external factors. Based on the empirical and mathematical models developed by past studies, Table 4 shows important factors affecting corrosion rate and initiation time of corrosion [34-52]. Among all factors, one may notice that increasing total chloride raises corrosion rate. This means that all factors affecting total chloride (see Table 2) influence corrosion rate. Increasing saturation degree of pore in empirical model causes both reduction and rising of corrosion rate. On the other hand, the mathematical model showed that increasing the degree of saturation pore from $30 \%$ to $50 \%$ causes increasing corrosion rate, while further increase from $60 \%$ to $100 \%$ causes reduction in corrosion rate [36].

While measuring corrosion accurately is difficult, there are some simple methods based on corrosion potential and corrosion rate that can be used by researchers and practical engineers to estimate active corrosion in RC structures. For example, according to ASTM C-876-91, if corrosion potential, $V$, is less than -0.35 , probability of active corrosion is more than 95\% [53]. Elsener et al. [54] have stated that corrosion potential ranging from -0.4 to -0.6 means that steel is corroding. Liang et al. [55] have reported that using corrosion current density to corrosion duration ratio the grade of corrosion can be evaluated according to Table 5 .

2.4. Corrosion By-Products and Corrosion-Induced Cracking. As discussed earlier, when corrosion initiates, corrosion byproducts are formed. The volume of corrosion by-products is greater than that of steel. Therefore, volumetric expansion causes tensile stress leading to propagation of cracks into concrete cover. Zhao et al. [56] have suggested the expansion coefficient of $2.64,2.85$, and 3.02 for samples corroded in 
TABLE 4: Important factors and their effects on corrosion rate and start time of corrosion.

\begin{tabular}{|c|c|c|c|}
\hline \multirow{2}{*}{ Factor } & \multirow{2}{*}{ Empirical corrosion rate $\left(r_{\text {corr }}\right)$ model } & \multicolumn{2}{|c|}{ Mathematical corrosion rate } \\
\hline & & Start time & $r_{\text {corr }}$ \\
\hline \multicolumn{4}{|c|}{ Steel condition } \\
\hline Temperature at steel level & $\uparrow$ & & \\
\hline Galvanic coupling & $\uparrow$ & & \\
\hline Corroding area to exposure area & & & $\downarrow$ \\
\hline Anodic and cathodic resistivity & & & $\uparrow$ \\
\hline \multicolumn{4}{|c|}{ Concrete and binder properties } \\
\hline $\mathrm{w} / \mathrm{c}$ ratio & $\uparrow$ & & $\uparrow$ \\
\hline Total $\mathrm{Cl}^{-} \%$ & $\uparrow$ & & \\
\hline $\mathrm{pH}$ & $\downarrow$ & & \\
\hline Electrical resistivity & $\downarrow$ & & $\downarrow$ \\
\hline Permeability & $\uparrow$ & & \\
\hline Cracks & & $\downarrow$ & $\mathrm{NC}$ \\
\hline Size distribution of aggregates & & $\downarrow$ & \\
\hline Initiation crack width & & $\downarrow$ & \\
\hline Degree saturation of pore & $\downarrow \uparrow$ & & $\begin{array}{c}(30 \%-50) \uparrow ; \\
(60 \%-100 \%) \downarrow\end{array}$ \\
\hline
\end{tabular}

\begin{tabular}{lr}
\hline Slag concentration & External facto \\
Chloride conductivity & $\downarrow$ \\
RH & $\uparrow$ \\
Time & $\uparrow$ \\
Oxygen availability & $\downarrow$ \\
Aging of oxides in dry concrete & \\
Aging of oxides in wet concrete & $\downarrow$ \\
Cover &
\end{tabular}

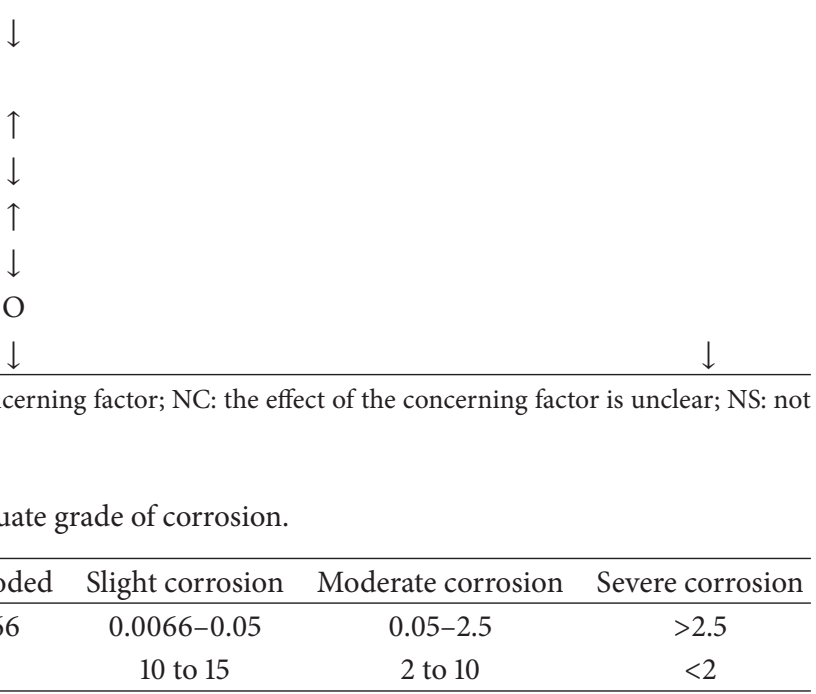

\begin{tabular}{lcccc}
\hline Corrosion grade & Noncorroded & Slight corrosion & Moderate corrosion & Severe corrosion \\
\hline Corrosion current density $\left[\mu \mathrm{A} / \mathrm{cm}^{2}\right] /$ corrosion duration [year] & $<0.0066$ & $0.0066-0.05$ & $0.05-2.5$ & $>2.5$ \\
Corrosion duration [year] & $>15$ & 10 to 15 & 2 to 10 & $<2$ \\
\hline
\end{tabular}

$\mathrm{NaCl}$ solution, near or on the coast and in splash zone, respectively. Table 6 presents the volume expansion of different components of corrosion by-product found by past studies.

Predicting the expansion volume of rusts is very important to improve the knowledge of service life of reinforced concrete structures. The variation in expansion coefficient reported by past studies clearly indicates that the need for further studies on rust compositions is demanded.

With respect to mechanical properties and characteristics of corrosion by-products, Caré et al. [57] have stated that Young's modulus of rust layers depends on the diameter of uncorroded steel bar and thickness of the rust layers. Zhao et al. [56] have shown that environmental parameters such as amount of humidity and oxygen availability vary the volume expansion coefficient. Increasing the amount of humidity and oxygen raises the expansion coefficient.
Past studies investigated corrosion-induced cracking and shared the influencing factors and measured crack width based on experimental data. A summary of 18 reviewed works has been presented in Table 7 showing crack width measured in addition to some details such as amount, current density, and/or type of corrosion and time of exposure. Table 7 can give an overall view on corrosion-induced cracking. It is worth noting that the maximum crack width reported in the literature so far has been $6 \mathrm{~mm}$ [31]. Few models have been developed for predicting width of crack in the literature. Andrade et al. [58], for example, presented a simple formula to predict average width of crack in elements exposed to natural corrosion [59]:

$$
w=k\left[\frac{P_{x}}{C / \phi}\right],
$$


TABLE 6: Volume expansion of corrosion by-product components.

\begin{tabular}{lccccccccccc}
\hline \multirow{2}{*}{ References } & \multicolumn{8}{c}{ Volume expansion coefficient of different components of corrosion by-product } \\
& $\mathrm{FeO}$ & $\mathrm{Fe}_{3} \mathrm{O}_{4}$ & $\mathrm{Fe}_{2} \mathrm{O}_{3}$ & $\alpha \mathrm{FeOH}$ & $\gamma \mathrm{FeOH}$ & $\mathrm{Fe}_{2} \mathrm{O}_{3} \cdot \mathrm{H}_{2} \mathrm{O}$ & $\beta \mathrm{FeOH}$ & $\mathrm{Fe}(\mathrm{OH})_{2}$ & $\mathrm{Fe}(\mathrm{OH})_{3}$ & $\mathrm{Fe}(\mathrm{OH})_{3} \cdot 3 \mathrm{H}_{2} \mathrm{O}$ & $\mathrm{Fe}_{2} \mathrm{O}_{3} \cdot 3 \mathrm{H}_{2} \mathrm{O}$ \\
\hline$[62]$ & 1.82 & 2.08 & 2.17 & - & - & - & - & 3.76 & 4.24 & 6.46 \\
{$[80]$} & 1.74 & 2.1 & $2.11,2.26$ & 2.9 & 3.12 & - & 3.5 & 3.7 & 4 & & - \\
{$[65]$} & 1.8 & 2 & 2.2 & - & - & - & - & 3.75 & 4.2 & 6.4 & - \\
{$[57]$} & - & 2.08 & 2.12 & 2.91 & 3.03 & - & 3.48 & - & - & - & - \\
{$[81]$} & 1.77 & 2.1 & 2.14 & 2.92 & 3.06 & 3.12 & - & 3.71 & 4.82 & - & - \\
{$[56]$} & - & 2.1 & - & 2.95 & 3.07 & - & 3.53 & - & - & - & - \\
\hline
\end{tabular}

TABLE 7: Relationship between crack widths with corrosion obtained from literature.

\begin{tabular}{|c|c|c|c|c|c|}
\hline References & Type of specimen & Time (day) & $i_{\text {corr }}\left(\mu \mathrm{A} / \mathrm{cm}^{2}\right)$ & $A_{\text {corr }}(\%)$ & Crack width $(\mathrm{mm})$ \\
\hline$[82]$ & Beam & NS & 2000 & $<4.5$ & 1.3 \\
\hline \multirow{2}{*}{ [83] } & Beam & $3-15$ & 0.5 & $2.5-12$ & $0.1-0.75$ \\
\hline & Bond-pull & & 500 & NS & NS \\
\hline [58] & Prism & $1-100$ & 10,100 & $0.5-2.5$ & $0.05-0.5$ \\
\hline \multirow{2}{*}{ [84] } & Beam & 28 & & $0.8-9.2$ & NS \\
\hline & Bond-pull & $1-28$ & & $3.6-19.2$ & $0.06-0.46$ \\
\hline [74] & Column & $106-204$ & 100 & $9.1-17.8$ & $0.8-4.0$ \\
\hline [75] & Beam & $100-200$ & 100 & $10.1-26.3$ & $0.2-0.6$ \\
\hline$[85]$ & Slabs & $1-2.5$ & 3 & $1-75$ & NS \\
\hline [86] & Beam & 126 hours & $5 \times 10^{8}$ & $<1$ & NS \\
\hline [43] & Prism & $68-221$ & 10,100 & NS & $0.06-1$ \\
\hline [87] & Prism & NS & $5 \mathrm{~V}$ current & 0,12 & $0.35,0.8$ \\
\hline$[88]$ & Beam & $15-18$ & $1-4$ & $2.5-10$ & NS \\
\hline [89] & Beam & $16-64 \mathrm{~h}$ & 3 & $1.25-5$ & NS \\
\hline$[31]$ & Prism & 700 & & Up to 51 & $0-6$ \\
\hline [90] & Prism & $815,766,380,306$ & $100,200,350,500$ & $4.38,7.3,6.5,7.26$ & $0.25-1$ \\
\hline \multirow{2}{*}{ [91] } & Beam & 17 years & \multirow{2}{*}{ Saline Environment } & 26 & 1.6 \\
\hline & Beam & 14 years & & 12 & 1.8 \\
\hline$[92]$ & Slab & 2-9 months & 100 & NS & $0.05-1.5$ \\
\hline \multirow{2}{*}{ [93] } & T-beam & $2-15$ years & \multirow{2}{*}{ Average: 0.128} & NS & $0.31-3.94$ \\
\hline & Column & $2-15$ years & & NS & $0.2-0.51$ \\
\hline [94] & Wall spec. & 20-56 weeks & $R_{p}= \pm 20 \mathrm{mV}$ & Up to $6.5 \%$ & $0.01-1$ \\
\hline
\end{tabular}

where $w$ is the crack width $(\mathrm{mm}), k$ is a nondimensional factor, $C / \phi$ is concrete cover/diameter of the bar ratio, and $P_{x}$ is penetration of the corrosion in time $t$ (year) and equal to

$$
P_{x}=0.0115 r_{\text {corr }} t
$$

where $r_{\text {corr }}$ (mm/year) is the corrosion rate.

Andrade et al. [59] validated their formula with 15-yearold RC specimens. They proposed $k=9.5$ for their formula. $\mathrm{Du}$ et al. [60] showed that both decrease of w/c (water to cement) ratio and increase of cover are important factors to resist cracking due to ingress of chloride. It is clear that rate of corrosion is always an important factor affecting crackinduced corrosion.
The relationship between corrosion current density, $i_{\text {corr }}\left(\mathrm{mA} / \mathrm{m}^{2}\right)$, and corrosion rate, $r_{\text {corr }}(\mu \mathrm{m} /$ year $)$, can be expressed in the following equation [61]:

$$
r_{\text {corr }}=\frac{0.327\left(M i_{\text {corr }}\right)}{n \rho},
$$

where $M(\mathrm{~g} / \mathrm{mol})$ is the atomic weight, $n$ is the ion valence, and $\rho$ is the density $\left(\mathrm{g} / \mathrm{cm}^{3}\right)$.

Predicting time of corrosion cracking is another important factor in corrosion-induced cracking topic and is used for predicting the service life of corroded RC structures. Predicting the time of corrosion cracking has been addressed by a number of researchers including [55]. In this regard, a few mathematical models have been developed by [62-67]. Figure 5 shows the relationship between percentage of cross 
TABLE 8: Corrosion-induced reduction factors of mechanical properties of steel reinforcing.

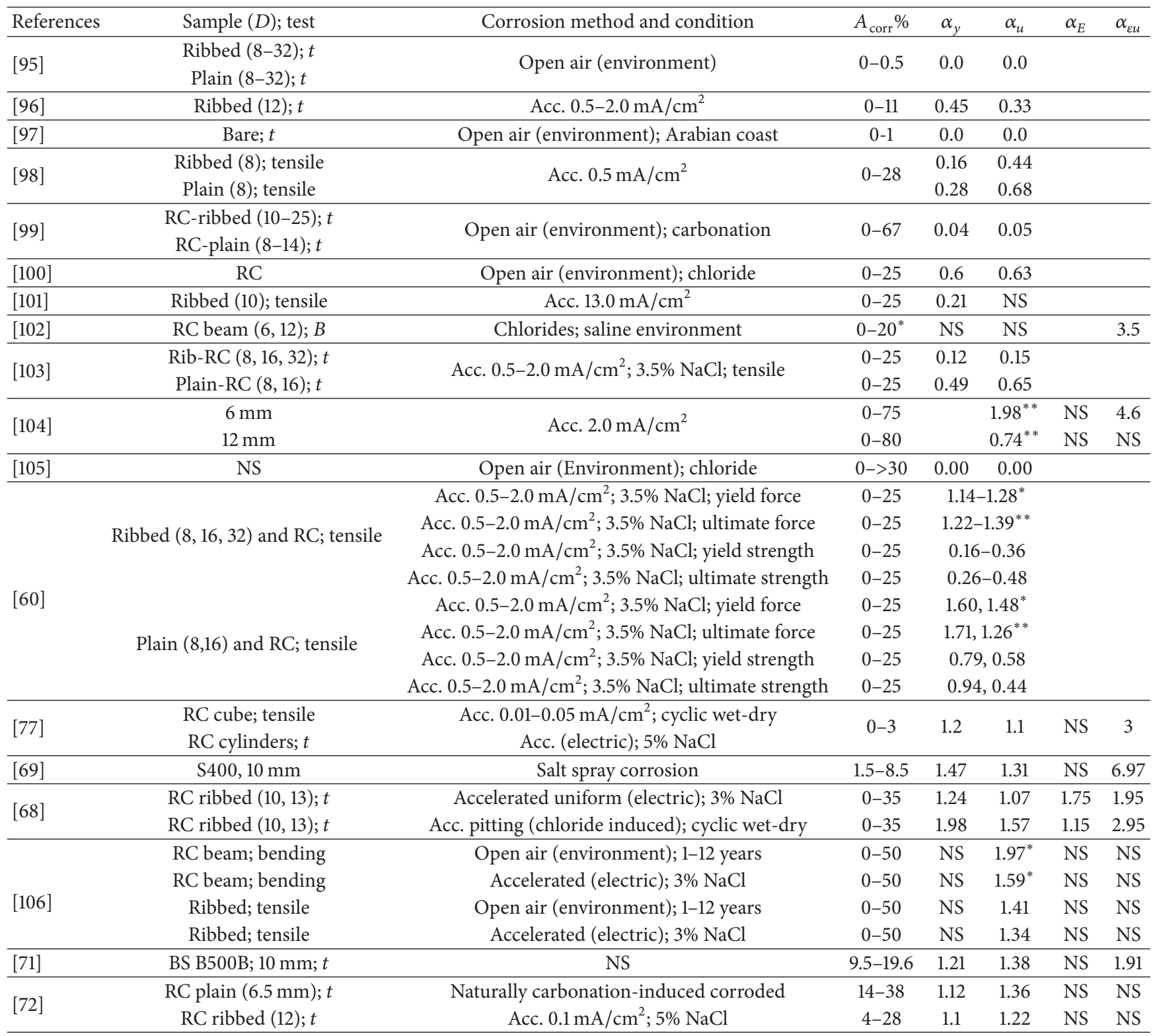

* indicates factor associated with yield force.

$* *$ indicates reduction factor associated with ultimate force.

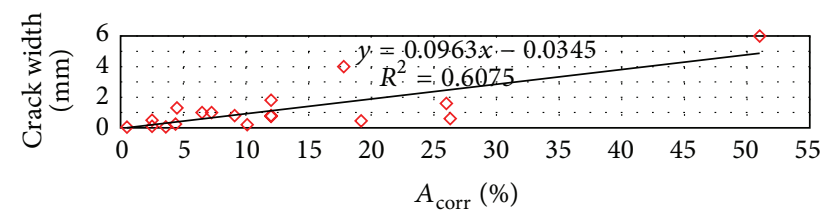

FIGURE 5: Crack width versus percentage loss of cross section regresses from results represented in Table 8.

section loss in steel bars and crack width $(\mathrm{mm})$ based on the results represented in Table 8. Figure 5 shows increasing percentage loss of cross section due to corrosion raising crack width.
The reason for rising crack width with corrosion percentage is that more corrosion by-products in higher level of corrosion lead to increase of crack width.

2.5. Research Gaps. The main research gaps in chlorideinduced corrosion can be summarized as follows:

(i) More accurate value of critical content of chloride concentration for real RC structures.

(ii) Factors and their effects on the critical content of chloride.

(iii) Robust pitting factors for real corroded structures.

(iv) Factors and their effects on corrosion rate and time of initiation. 
(v) Robust corrosion rate and time of initiation prediction.

(vi) More accurate values volume expansion for corrosion by-product and rust components, especially for real corroded RC structures.

Research studies aiming to fill the above research gaps will lead to decrease of uncertainties in estimation of chlorideinduced corrosion.

\section{Corrosion-Induced Deterioration of RC Structures}

As discussed earlier, the two main outcomes of corrosion are decreasing cross section area of steel reinforcement and volumetric expansion caused by corrosion by-products. As a result, mechanical properties of steel reinforcement such as modules of elasticity, force, stress and strain at yield, and ultimate points alter with corrosion. Regarding cyclic behavior of steel reinforcement, in particular, corrosion changes energy dissipating characteristic and number of cycles needed for failure. Bond between concrete and steel varies in corroded reinforced concrete members. The stressstrain model of confined concrete in compression region is affected by corrosion and maximum compression stress of concrete decreases because of cracks propagated into concrete cover due to corrosion. Up to date, there is no experimental study showing the effects of corrosion on stressstrain relationship on $\mathrm{RC}$ columns. It is worth noting that the similar experimental study is in progress by authors. Therefore, materials characteristics of corroded reinforced concrete members have to be applied for analyses and simulations of corroded structures.

3.1. Effect of Corrosion on Mechanical Properties of Steel Reinforcing. Irregular decreases in cross-sectional area of steel reinforcing cause changes in mechanical properties of reinforcements. A number of monotonic tensile tests on bare bars and RC elements and bending tests on RC beams and slabs have been carried out to estimate the reduction factors corresponding to the mechanical properties. Reduction factors indicate the percentage of reductions in mechanical properties that will happen for $1 \%$ reduction in cross section, and they have been estimated from experimental results and reported by past studies. In this paper, a survey on 18 experimental works has been done and the results and references have been presented in Table 8 . The following investigated mechanical properties were included: yield and ultimate (stress or force) strength, elongation, and module of elasticity. Equations (5)-(10) are typical models regressed from experimental data used by past studies that can be used to calculate mechanical properties of corroded steel reinforcements:

$$
\begin{aligned}
\sigma_{y}^{c} & =\left[100-\alpha_{y} \times A_{\text {corr }} \%\right] \sigma_{y}, \\
\sigma_{u}^{c} & =\left[100-\alpha_{u} \times A_{\text {corr }} \%\right] \sigma_{u}, \\
E_{s}^{c} & =\left[100-\alpha_{E} \times A_{\text {corr }} \%\right] E_{s},
\end{aligned}
$$

$$
\begin{aligned}
\delta_{s}^{c} & =\left[100-\alpha_{\varepsilon u} \times A_{\text {corr }} \%\right] \delta_{s}, \\
F_{y}^{c} & =\left[100-\alpha_{y}^{*} \times A_{\text {corr }} \%\right] F_{y}, \\
F_{u}^{c} & =\left[100-\alpha_{u}^{* *} \times A_{\text {corr }} \%\right] F_{u},
\end{aligned}
$$

where $\sigma_{y}^{c}, \sigma_{u}^{c}, E_{s}^{c}, \delta_{s}^{c}, F_{y}^{c}$, and $F_{u}^{c}$ are yield stress, ultimate stress, module of elasticity, elongation, yield force, and ultimate force of corroded bars, respectively, $\alpha_{y}, \alpha_{u}, \alpha_{E}, \alpha_{\varepsilon u}, \alpha_{y}^{*}$, and $\alpha_{u}^{* *}$ are their associated reduction factors, $A_{\text {corr }} \%$ is the percentage loss of cross section, and $\sigma_{y}, \sigma_{u}, E_{s}, \delta_{s}, F_{y}$, and $F_{u}$ are yield stress, ultimate stress, module of elasticity, elongation, yield force, and ultimate force of noncorroded bars.

While the results presented in the literature have a wide variation, some conclusions reported by the above reviewed references are as follows:

(i) Very low corrosion may not affect the mechanical properties of the steel reinforcing.

(ii) Usually, reduction factors for environment corrosion and plain steel reinforcement are higher than accelerated corrosion and deformed steel reinforcement.

(iii) The greatest reduction factor is related to elongation. This is very important for seismic behavior of RC structures.

(iv) Usually, pitting corrosion and irregularities in corrosion increase the reduction factors. On the other hand, reduction factors for pitting corrosion are greater than those for general corrosion [68].

(v) The reduction factors for corroded bare steel reinforcement and those corroded while embedded in concrete are similar [60].

(vi) The effects of the type (plain or deformed type) and diameter of reinforcing steels on reduction factors can be neglected [60].

To illustrate the variation of the published reduction factors, the minimum and maximum reduction factors of four mechanical properties of steel reinforcement based on the data represented in Table 8 are shown in Figure 6 . The mechanical properties include elongation, modulus of elasticity $(E)$, yield stress, and ultimate stress. Since linear regression has been employed by all past studies to estimate reduction factors, the minimum and maximum reduction factors shown in Figure 6 are represented based on linear regression.

Figure 6 shows that corrosion deteriorates the mechanical properties of reinforcing steel. However, there are big variations in results published in the literature based on monotonic tests. The results also show that the maximum reduction factors and the greatest difference between minimum and maximum reduction factors have been reported for elongation.

A few number of studies identified cyclic behavior of corroded steel reinforcements. Apostolopoulos and Papadopoulos [69] have shown that a mass loss less than $2 \%$ and $3 \%$ causes $22 \%$ and $47 \%$ reduction to the number of maximum 

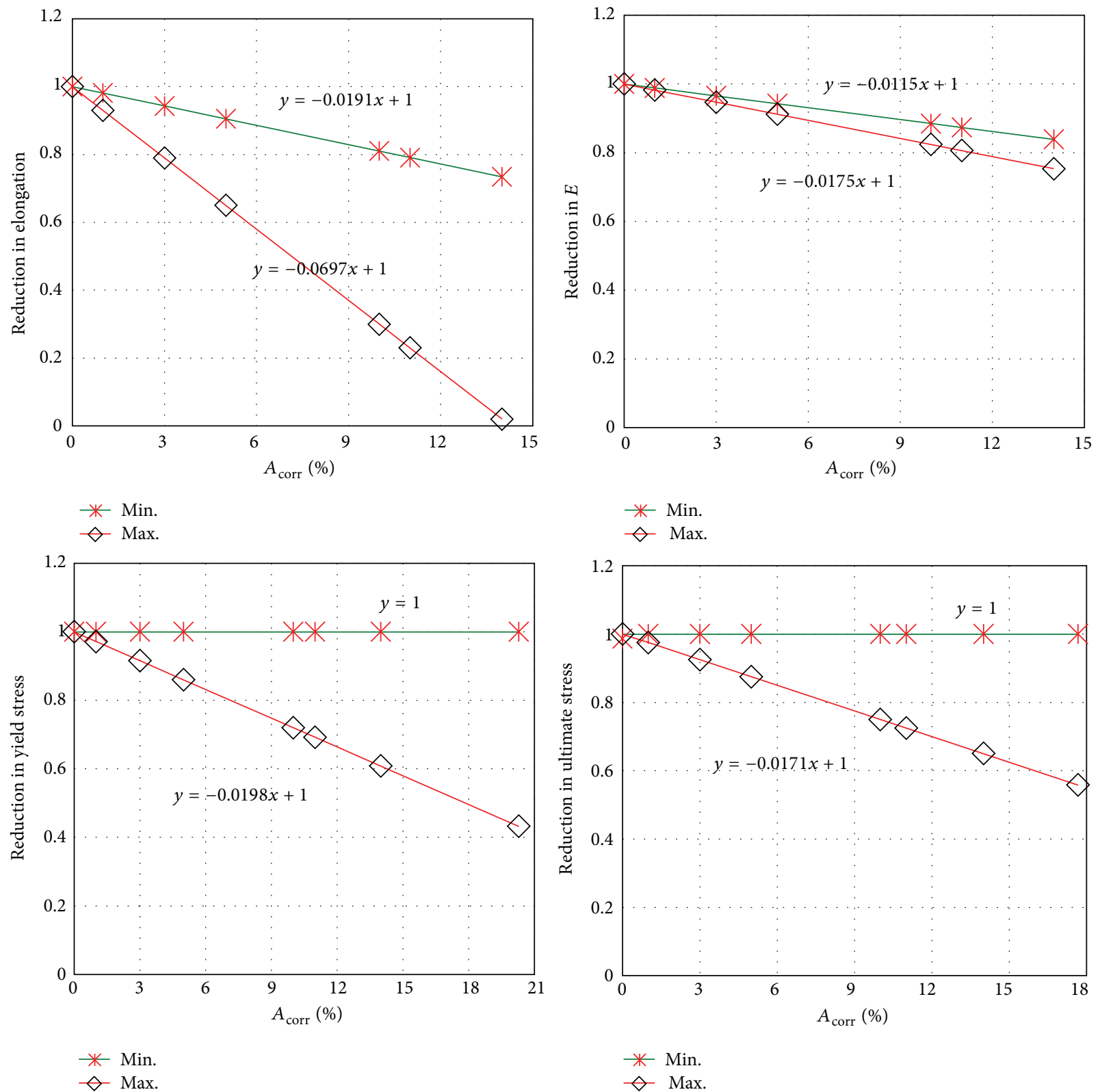

FIGURE 6: Maximum and minimum reduction factors for elongation, modulus of elasticity, yield stress, and ultimate stress.

cycles required for rupture, respectively. Apostolopoulos and Pasialis [70] have studied the low cycle fatigue behavior of smooth and ribbed steel reinforcement for different degrees of corrosion. They have reported that smooth bars showed a better cyclic behavior than that of ribbed bars for low strain amplitude and up to $8 \%$ loss of mass due to corrosion. On the other hand, smooth bars can dissipate more energy and need higher number of cycles to fail in low strain magnitude $( \pm 1 \%)$ than those of ribbed bars. These advantages disappear as strain amplitude increases. Hawileh et al. [71] studied the effect of corrosion on cyclic behavior of BS B500B bars. They have demonstrated that corrosion decreases low cycle fatigue life of the bars. They have pointed out that lower strain amplitude $( \pm 4 \%)$ causes more reduction in dissipating energy and more cycles are needed for failure than those of higher strain amplitude $( \pm 6 \%)$. Zhang et al. [72] have found that increasing the degree of corrosion causes reduction in fatigue life of corroded bars. They also have claimed that the impact of corrosion on fatigue behavior and naturally corroded steel bar is more than that on monotonic behavior and artificially corroded steel bar, respectively.

3.2. The Effects of Corrosion on Bond Strength between Steel and Concrete. Table 9 shows the effect of the percentage of corrosion on bond strength based on 16 experimental works reviewed by the authors. As an overall trend, low corrosion percentage increases the bond strength, while high percentage of corrosion always decreases the bond strength. 
TABLE 9: Effect of corrosion on bond strength between concrete and steel reinforcement.

\begin{tabular}{|c|c|c|c|c|c|}
\hline Authors and date & Sample $(D)$; test & Corrosion method & Time exposure & $A_{\text {corr }} \%$ & Bond strength; \% of change \\
\hline \multirow{7}{*}[82]{} & $14 \mathrm{~mm}$ bending & \multirow{7}{*}{$2000 \mu \mathrm{A} / \mathrm{cm}^{2}$} & \multirow{7}{*}{ NS } & 0.55 & $\uparrow ; 40$ \\
\hline & $10 \mathrm{~mm}$ pullout & & & 0.55 & $\uparrow ; 42$ \\
\hline & $10 \mathrm{~mm}$ pullout & & & $3.5-7.4$ & $\downarrow ; 0-66$ \\
\hline & $14 \mathrm{~mm}$ pullout & & & 0.65 & $\uparrow ; 28$ \\
\hline & $14 \mathrm{~mm}$ pullout & & & $2.6-5.7$ & $\downarrow ; 0-65$ \\
\hline & $20 \mathrm{~mm}$ pullout & & & 0.43 & $\uparrow ; 25$ \\
\hline & $20 \mathrm{~mm}$ pullout & & & $1.6-4$ & $\downarrow ; 0-47$ \\
\hline \multirow{4}{*}{ [107] } & \multirow{4}{*}{$12 \mathrm{~mm}$, pullout } & \multirow{4}{*}{0.4 A current electric } & \multirow{4}{*}{ NS } & $<4$ & $\uparrow ; 17$ \\
\hline & & & & $5-7$ & $\downarrow ; 30-69$ \\
\hline & & & & $8-12$ & $\downarrow ; 70-78$ \\
\hline & & & & $12-80$ & $\downarrow ; 78-86$ \\
\hline \multirow{2}{*}[84]{} & \multirow{2}{*}{$12 \mathrm{~mm}$, pullout } & \multirow{2}{*}{ 2-64 A current electric } & \multirow{2}{*}{$<28$ days } & 0.7 & $\uparrow ; 18$ \\
\hline & & & & $2.42,12$ & $\downarrow ; 5,60$ \\
\hline \multirow{2}{*}{ [108] } & \multirow{2}{*}{$19 \mathrm{~mm}$, pullout } & \multirow{2}{*}{ Saturated in $\mathrm{Ca}(\mathrm{OH})_{2}$} & $<5$ weeks & NS & $\uparrow ; \mathrm{NS}$ \\
\hline & & & $>5$ weeks & NS & $\downarrow ; \mathrm{NS}$ \\
\hline [5] & $10 \mathrm{~mm}$, bending & 0.1 A current electric & 21-63 days & 20 & $\downarrow ; 74$ \\
\hline$[6]$ & $19 \mathrm{~mm}$, pullout & 12 A current electric & $>3$ days & $0-5.2$ & $\downarrow ; 78$ \\
\hline \multirow{4}{*}{ [7] } & \multirow{4}{*}{$13 \mathrm{~mm}$, pullout } & \multirow{4}{*}{ 1A current electric } & NS & 3 & $\downarrow ; 35$ \\
\hline & & & NS & 16.8 & $\downarrow ; 77$ \\
\hline & & & NS & $13^{*}$ & $\downarrow ; 13$ \\
\hline & & & NS & $24^{*}$ & $\downarrow ; 38$ \\
\hline \multirow{2}{*}{ [109] } & \multirow{2}{*}{$10 \mathrm{~mm}$, pullout, $15 \mathrm{~mm}$ cover specimen } & \multirow{2}{*}{$140 \mu \mathrm{A} / \mathrm{cm}^{2}$} & \multirow{2}{*}{ NS } & 5 & $\uparrow ; \cong 15$ \\
\hline & & & & 10 & $\downarrow ; \cong 35$ \\
\hline \multirow{2}{*}[110]{} & \multirow{2}{*}{$10 \mathrm{~mm}$, bending } & \multirow{2}{*}{12 A current electric } & \multirow{2}{*}{ NS } & 2 & $\uparrow ; 30$ \\
\hline & & & & $2.8,15$ & $\downarrow ; 0,77$ \\
\hline \multirow{3}{*}[111]{} & Deformed pullout & & & 4,9 & $\downarrow ; 45,68$ \\
\hline & Deformed pullout & $0-2$ A current electric & 10-12 days & $3.8^{*}, 6^{*}$ & $\downarrow ; 4,12$ \\
\hline & Smooth, pullout & & & 3.3 & $\uparrow ; 21$ \\
\hline [8] & $20 \mathrm{~mm}$, pullout & 0-2 A current electric & NS & 4 & $\downarrow ; 45$ \\
\hline ] & & -2 & 100 & $3.8^{*}$ & $\downarrow ; 5$ \\
\hline [112] & $20 \mathrm{~mm}$, pullout & $500 u \mathrm{~A} / \mathrm{cm}^{2}$ & $8-48 \mathrm{~h}$ & $0.2,0.36$ & $\uparrow ; 50,20$ \\
\hline & & 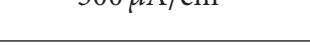 & $56-96 \mathrm{~h}$ & $0.4,0.76$ & $\downarrow ; 20,84$ \\
\hline Berto et al. [9] & $10 \mathrm{~mm}$, pullout & NS & NS & 4.27 & $\downarrow ; 12$ \\
\hline & & & & 7.8 & $\downarrow ; 75$ \\
\hline Chung et al. [113] & $13 \mathrm{~mm}$, pullout & 12 A current electric & $>3$ davs & $<3$ & $\uparrow ; 40$ \\
\hline & & & & $3-7$ & $\downarrow ; 27$ \\
\hline & Deformed, $20 \mathrm{~mm}$ pullout & & & $0.6^{*}, 11^{*}$ & $\downarrow ; 6,50$ \\
\hline Kivell [10] & & 0.1 A current electric & $10-50$ days & $20^{*}$ & $\downarrow ; 76$ \\
\hline & Def. $20 \mathrm{~mm}$ cyclic & & & $18.6^{*}$ & $\downarrow ; 59$ \\
\hline
\end{tabular}

$\downarrow \uparrow$ indicates decreasing and increasing bond strength of corroded bar in comparison with sound bar; $*$ indicates confined reinforced concrete. It should be noted that increasing cycles also cause a reduction in bond strength.

Type of steel bars and confinement are the important factors that influence the change of bond strength due to corrosion. In spite of the above general trends, the variation is very high indicating the significance of further investigation in this area. Since chloride-induced corrosion is a function of concrete cover and stirrups always have less cover than longitudinal bars, further research should be performed to consider this problem that to the best of the authors' knowledge there is no report on in the literature. Moreover, high level of corrosion causes a critical reduction in bond under cyclic loading, while corrosion under 5\% increases bond capacity [114]. It has been reported that confinement efficiently decreases bond degradation under cyclic loading [114].

The information collected in Table 9 has been graphically presented in Figure 7. Figure 7, therefore, shows bond strength of corroded to noncorroded steel reinforcement ratio over corrosion percentage based on past published 


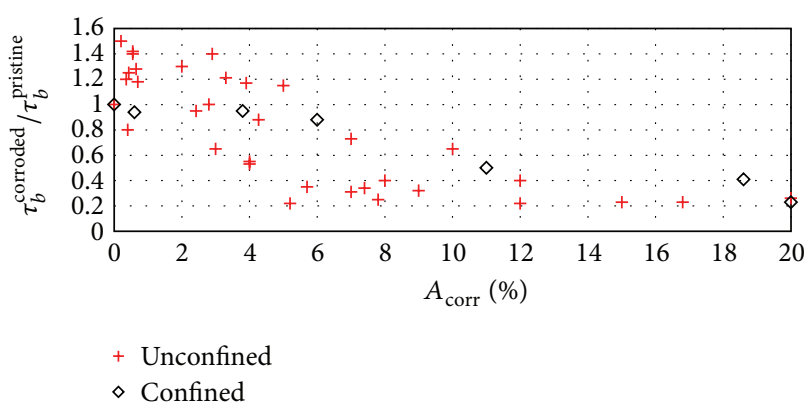

FIgURE 7: The relationship between bond strength of corroded to noncorroded reinforcing steels and corrosion for confined and unconfined RC samples based on collected experimental results.

experimental studies. The data have been classified into two groups including confined and unconfined RC samples.

\subsection{The Effects of Corrosion on Stress-Strain Model of Confined} Concrete. As far as confinement is concerned, corrosion of lateral steel bars alters confinement properties of reinforced concrete members. However, there is no evidence indicating how the stress-strain model of a confined concrete changes due to corrosion. Mander et al. [115] stated that "confinement is defined as sufficient lateral reinforcement in the form of the circular or rectangular arrangement of steel." They also stated that "the aim is to confine reinforced concrete members under compression to avoid the buckling of longitudinal bars, and to prevent shear failure." Confinement is a critical factor in plastic hinge region, because it ensures the ductility capacity demanded in seismic events. Transversal steel reinforcements are the closest steel bars to the surface of RC members. Therefore, they are corroded more severely than longitudinal bars. The effect of corrosion on confinement is very rare and only one report [116] was found on this subject in the literature. Ou et al. [116] analytically calculated confining strength ratio based on corroded steel reinforcing and ultimate strain of confined concrete based on reduction in mechanical properties of reinforcing steels. It is clear that further investigation is needed in this area. A study in this area is in progress by authors at the University of Canterbury.

3.4. The Effects of Corrosion on Concrete Strength of Reinforced Concrete Structures. As discussed earlier, corrosion causes propagating cracks into concrete core, influencing compression and tensile strength of concrete material. A few studies have identified the effects of cracks on tensile and compression strength of concrete materials. Vecchio and Collins [117], for example, presented the following equation that addresses the effect of cracks on the compressive strength of concrete:

$$
f_{c}^{*}=\frac{f_{c}}{0.8-0.34 \varepsilon_{1} / \varepsilon_{c}}
$$

where $f_{c}^{*}$ is compression stress of cracked concrete, $f_{c}$ is maximum compression stress of noncracked concrete, and $\varepsilon_{1} / \varepsilon_{c}$ is the ratio of principle tensile strain to maximum strain corresponding to maximum compression stress $\left(f_{c}\right)$. It is clear that $\varepsilon_{1} / \varepsilon_{c}$ is negative.

The above equation has been improved by the following research studies $[118,119]$.

Further investigation is critically needed to identify the effects of corrosion on concrete cracks and consequent concrete strength.

\subsection{Time-Dependent Deterioration Models for Reinforced} Concrete Members. Corrosion and consequent degradation are time-dependent. Therefore, deterioration models are time variant mathematical equations showing relationships between the deteriorated mechanical properties and time. For example, with replacement of $A_{\text {corr }}$ with an equation showing relationship between $A_{\text {corr }}$ and time, (4) to (9) will be timedependent deterioration models for mechanical properties of reinforcing steels.

There are two different types of deterioration models for RC structures called macro model and micro model. The macro deterioration model has been developed based on growing micro cracks. Growing micro cracks lead to macro cracks and also to accelerated ingress of aggressive ions [120, 121].

The micro deterioration model frequently used in the literature has been developed based on three models including transport model of aggressive ions, electrochemical model of corrosion, and structural model. The structural model can be developed corresponding to decrease of dimension, reduction in strength, or increase of cracks [121]. Fick's second law of diffusion is used for ion transport model [24]. There are a few studies that have been developed on the degradation of reinforced concrete structures due to corrosion [3, 122-124].

3.6. Main Research Gaps. The main research gaps in corrosion-induced deterioration of RC structures can be summarized as follows:

(i) Robust deterioration model for corroded steel reinforcement considering cyclic behavior of steel reinforcement in seismic events.

(ii) Robust deterioration model to predict bond between steel and concrete in corroded RC structures.

(iii) Corrosion-induced stress-strain model of confined concrete.

(iv) Corrosion influencing compression strength of concrete.

\section{Evaluation of Seismic Performance of Corroded Reinforced Concrete Bridge Piers}

According to what has been discussed so far, corrosion degrades mechanical and structural characteristics leading to negative impact on seismic performance of RC structures. Bridge piers are earthquake-resistant elements of bridges. 
Therefore, assessing seismic performance of bridge piers exposed to corrosion is very important. Numerical simulation of corroded bridge piers is very complicated, and a number of uncertainties have limited utilizing the numerical simulation. On the other hand, both numerical and experimental investigations are needed for a comprehensive study on long-term seismic performance of corroded bridge piers. A number of studies have developed methods and formulations to predict initiation and propagation time of corrosion, corrosion cracking time, time of breaking of bond between steel and concrete, minimum load carry capacity, maximum deformation, maximum permeability, or failure probability [55, 125-130]. Then, developing methodologies for performance-based earthquake engineering and developing seismic fragility of bridges made a basis to evaluate seismic performance of RC bridges and other structures using fragility curves based on probability of failure [131-137]. The seismic performance assessment using fragility function can be applied for either a member or the whole bridge structure. Recently, Akiyama and Frangopol [138] have presented a procedure to estimate life-cycle seismic reliability of corroded bridge piers based on integration of probabilistic assessment of seismic and airborne chloride hazard. Ou et al. [116] have developed a simple seismic evaluation of corroded RC bridges based on nonlinear static pushover analysis. They have presented seismic capacity and demand of the RC bridges in terms of peak ground acceleration (PGA). Actually, the number of years that the seismic demand (collapse PGA) becomes greater than the seismic capacity (design PGA) has been calculated for real RC bridges.

However, as mentioned earlier, difficulties and uncertainties in numerical simulation of RC bridge piers subjected to corrosion and seismic hazards indicate critical needs for further investigation, and advanced numerical methods are needed in this content. The next generations of numerical methods to evaluate seismic performance of corroded RC bridge piers are possibly as follows:

(i) Developing a new formulation of finite element methods based on fiber element or fiber beam method [139].

(ii) Real-time signal processing and finite element model updating of existing bridges based on vibration and corrosion potential measurements.

(iii) Artificial intelligence methods such as genetic algorithm [140].

4.1. Numerical Methods to Simulate Degradation of Reinforced Concrete Bridge Piers Exposed to Corrosion. Numerical methods to simulate seismic behavior of RC bridge piers exposed to corrosion can be classified into three groups including cross section, member, and system level analysis. This classification is similar to the one applied for noncorroded RC bridge piers. The integration of nonlinear analysis and finite element method is a popular numerical method that has been used for corroded and noncorroded RC bridge piers [140-143]. According to the literature, remarkable results obtained from numerical simulations of seismic behavior of bridges with corroded RC piers can be summarized as follows:

(i) Corrosion alters mechanism of collapse [143].

(ii) Corrosion decreases load carrying capacity due to increasing seismic demand and decreasing seismic capacity leading to increase of probability of failure [144-146].

(iii) Corrosion increases uncertainty in probabilistic model-based analysis models [147].

Cross section level analysis is probably the oldest numerical method among the three methods used to simulate deterioration of RC bridge piers. Corrosion causes damage to concrete material and bond between steel and concrete leading to loss in section ductility. The loss of section ductility can be calculated using moment-curvature analysis [148, 149]. There are some studies where degradation of RC bridge piers caused by corrosion has been investigated using moment-curvature analysis of cross section. Seismic capacity of corroded cross section can also be achieved using the cross section level analysis [143, 145, 150, 151].

Member level analysis is a numerical method providing an opportunity to evaluate the seismic performance of whole corroded bridge piers. Finite element formulation is used to simulate seismic behavior of a corroded bridge pier. To this aim, a relationship, for example, between lateral force and displacement is developed [152]. The simulation should take into consideration deterioration models to simulate degradation due to corrosion. Failure modes and seismic response of corroded RC bridge piers can be obtained from the member level analysis.

System level analysis is aiming to assess dynamic response of a corroded bridge exposed to ground motions. There are a number of studies in the literature where the system level analysis of corroded bridges has been done using fragility estimation [124, 144-146, 153]. However, Lv et al. [142], for example, have evaluated the effects of corrosion on seismic performance of curved beam with height piers using timehistory analysis of the bridge finite element model. They found that corrosion deteriorates the seismic performance of the bridge, and two main factors including pier-height and pier-corrosion are responsible for increasing plastic strain.

4.2. Large Scale Experimental Tests to Evaluate Seismic Performance of Corroded Bridge Piers. As mentioned earlier, numerical simulations of corroded bridge piers are very complicated and they probably cannot capture all the effects of corrosion on seismic performance of bridge piers. Therefore, large scale experimental tests need to assess seismic performance of corroded bridge piers. Some studies have been reported on the effects of corrosion on cyclic behavior of RC columns $[154,155]$. However, according to the best knowledge of the authors, large scale seismic experimental test on corroded bridge piers is rare and only one case [139] was found in the literature. Dietz et al. [139] designed a reinforced concrete bridge pier to EC2. They corroded the bridge pier using accelerated corrosion technique by ponding a part of the pier in $\mathrm{NaCl}$ solution for 6 months. The corroded 
bridge pier was then subjected to lateral cyclic loading up to $50 \mathrm{KN}$ using a hydraulic actuator. They measured deflection at the top, rotation at the base, strains in the concrete and steel bars, and width of cracks. From a structural point of view, the bridge pier rigidly connected to the foundation is high damage system because formation of plastic hinge at the end(s) of the pier is the mechanism of dissipating energy in seismic events. The high damage system is the traditional seismic resistant system that has been criticized by past studies because of high repair time and cost and problems arising from traffic interruption [156].

4.3. Seismic, Structural, and Durability Behavior of Repaired Bridge Piers Exposed to Corrosion-Induced Damage. The need for retrofit of corroded bridge piers has been addressed by past studies. There is a traditional method to rehabilitate corroded bridge pier that includes two stages: first, all critically corroded areas should be removed; then, an overlay of materials with low-permeability has been used [157, 158]. Gergely et al. [159] rehabilitated corroded bridge pier samples using fiber-reinforced plastic composites. They compared seismic performance of the piers through numerical and large scale experimental tests and found that shear capacity and ductility have been improved significantly. However, to simulate the effect of corrosion on steel reinforcement, they cut three stirrup loops of column and three stirrup loops of each side of the cap-beam near the joint. They noted that an advantage of using FRP composite is that it does not increase weight of column. Toutanji [160] has found that the confinement provided by FRP warps improves compression strength and ductility of RC columns. However, durability is affected by the type of epoxy used. Demers and Neale [161] have showed that the type of FRP influences ductility and strength of RC columns. Pantazopoulou et al. [162] compared alternative methods to assess seismic performance of repaired corroded bridge piers using external fiber-reinforced polymer (FRP) wraps. They stated that the best repair strategy in terms of postrepair corrosion, strength recovery, and ductility was cleaning the damaged surface (without removal of materials) and then jacketing using layers of FRP. However, further experiments are needed to confirm the efficiency of the proposed strategy in practice. Baiyasi and Harichandran [163] have concluded that a greater amount of glass fiber than carbon fiber was needed to achieve the equivalent structural performance of postcorrosion repair. Teng et al. [164] have reported that while FRP increases durability characteristics of RC columns, it possibly has some negative impacts on mechanical properties of the RC columns. A number of studies have revealed that FRP does not fully stop chlorideinduced corrosion but decreases the rate of corrosion [162, 163, 165-173]. To answer an important question of what the best strategy is to repair corroded bridge pier using FRP, Sen [169] stated that the best strategy to protect concrete columns against chloride-induced corrosion is applying FRP jackets and filling gaps between the column and jackets using epoxy so that the following conditions are satisfied:

(i) Applying FRP jacket over the full length when no visible corrosion-induced sign can be found. (ii) Utilizing appropriate epoxy as a surface corrosion barrier and filling gap between the column and jacket.

(iii) Utilizing at least two layers of FRP.

Sen [169] has argued that confined concrete by FRP warps changes corrosion diffusion. He also has recommended not using FRP warps before visible corrosion sign to minimize repair cost. Wootton et al. [170] have concluded that FRP warps protect the RC columns better than epoxy alone. It has been shown that low amount of corrosion (up to $4.2 \%$ ) does not influence eccentric load carrying capacity of RC columns, and the strength of damaged columns fully warped with carbon FRP was higher than undamaged columns. The performance of full length covered by CFRP was better than that partially covered by CFRP [174]. Li et al. [175] have analyzed seismic performance of corroded RC columns confined by FRP and steel jacket. They showed that FRP and steel jacket enhance the seismic performance of RC columns, and applying both jackets improves seismic performance better than applying one alone. A recent survey carried out on corroded RC bridges in New York State emphasized the demand for retrofitting corroded RC bridge columns, in particular, corroded lap-splice, to decrease possible damage in future seismic events [176].

4.4. Development in Time-Dependent Seismic Evaluation of Corroded RC Bridge Piers Reported in the Literature. Traditional structural analysis is not able to analyze systems and structures under multiple time-invariant hazards. A timedependent analysis during lifetime, therefore, is needed to take into consideration all hazards. In case of RC structures (in particular RC bridge pier) subjected to corrosion and earthquake, two hazards are corrosion-induced deterioration and seismic events. There are some studies in the literature, mainly published in recent years, showing that corrosion influences the seismic performance of bridge piers over time. However, different criteria have been used by past studies. Biondini et al. [151], for example, have presented time-dependent bending moment resistance of a bridge pier exposed to corrosion. They have shown that the bending moment resistance of the corroded bridge pier decreased over time. Time-dependent deformation capacity, drift ratio demand, shear capacity, and demand of a corroded bridge pier have been studied [93, 124, 144]. Time-dependent probability of failure (time-dependent fragility analysis) of corroded bridge piers has been developed by past studies that can be directly used for seismic analysis purposes [93, 124, $144,145,177,178]$. Moreover, a fragility increment function has been developed that is a function of time and given deformation or shear demand and can be used to predict fragility of corroded bridge piers in life-cycle analysis and risk assessment [147, 178].

4.5. Research Gaps. The main research gaps in evaluation of seismic performance of corroded reinforced concrete bridge piers can be summarized as follows:

(i) Robust numerical modelling of corroded bridge piers. 
(ii) Large scale experimental tests on seismic behavior of corroded bridge piers and bridge structures (half scale and full scale tests).

(iii) Experimental tests on efficiency of repair methods used for corroded bridge piers.

(iv) Robust numerical model to evaluate time-dependent seismic performance of RC bridges exposed to corrosion.

\section{Conclusions}

In this paper, chloride-induced corrosion, the effects of corrosion on structural and mechanical properties of RC structures or elements, and seismic performance of corroded $\mathrm{RC}$ bridge pier have been reviewed. To meet this aim, a large number of published papers with all their experimental and numerical details have been collected and reviewed. From the present literature review, the following main conclusions are drawn:

(1) The results of published papers represented in this review paper have been obtained from samples or structures mainly utilizing ordinary Portland cement material, and the behavior of upcoming and more recent cement materials need further investigations.

(2) Damage prediction of RC structures due to chlorideinduced corrosion significantly depends on estimation of important input parameters such as corrosion rate, critical content, limit step to start pitting corrosion, and corrosion-induced cracking. However, results reported by past studies exhibit critical problems including contradictory results and uncertainty in experimental techniques and reported results. Moreover, the obtained results cannot be transferred to real structures. Therefore, further investigations are needed in these areas.

(3) More reliable deterioration models are highly demanded for seismic evaluation and analysis of corroded RC structures. On the other side, the deterioration models have been mainly developed for artificial corroded samples, while the relationship between natural and artificial corrosion in many aspects is unknown. Hence, this area is an important direction of research.

(4) Seismic analysis of corroded RC structures (in particular bridge piers) is very complicated, and many uncertainties limit utilizing of numerical methods. Hence, developing more recent numerical methods and large scale experimental tests is needed for the analysis of RC structures under multiple hazards (corrosion and earthquake).

(5) While few researchers based on their modelling have already started to build fragility functions to be integrated in a lifetime seismic performance framework, still many gaps need to be covered in testing and modelling.
(6) Long-term seismic performance of RC bridge pier exposed to chloride incorporates the three main subareas reviewed in Sections 2 to 4 in this paper aiming to develop the following steps that are in common with LCA of corroded RC bridge piers:

(7) Time-dependent deterioration models.

(8) Time-dependent seismic performance of corroded structure.

\section{Competing Interests}

The authors declare that they have no competing interests.

\section{Acknowledgments}

The research program was supported by the Natural Hazards Research Platform (NHRP) project named "Advanced Bridge Construction and Design for New Zealand (ABCD - NZ Bridges)," 2011-2015. The authors gratefully acknowledge the support from NHRP.

\section{References}

[1] B. Hansen, "ASCE's infrastructure report card gives nation a D, estimate cost at \#.2 trillion," ASCE News, vol. 34, no. 2, pp. 1-4, 2009.

[2] R. R. Hussain and T. Ishida, "Critical carbonation depth for initiation of steel corrosion in fully carbonated concrete and development of electrochemical carbonation induced corrosion model," International Journal of Electrochemical Science, vol. 4, no. 8, pp. 1178-1195, 2009.

[3] K. A. T. Vu and M. G. Stewart, "Structural reliability of concrete bridges including improved chloride-induced corrosion models," Structural Safety, vol. 22, no. 4, pp. 313-333, 2000.

[4] D. Coronelli and P. Gambarova, "Structural assessment of corroded reinforced concrete beams: modeling guidelines," Journal of Structural Engineering, vol. 130, no. 8, pp. 1214-1224, 2004.

[5] K. Stanish, R. D. Hooton, and S. J. Pantazopoulou, "Corrosion effects on bond strength in reinforced concrete," ACI Structural Journal, vol. 96, no. 6, pp. 915-921, 1999.

[6] Y. Auyeung, P. Balaguru, and L. Chung, "Bond behavior of corroded reinforcement bars," ACI Materials Journal, vol. 97, no. 2, pp. 214-220, 2000.

[7] H.-S. Lee, T. Noguchi, and F. Tomosawa, "Evaluation of the bond properties between concrete and reinforcement as a function of the degree of reinforcement corrosion," Cement and Concrete Research, vol. 32, no. 8, pp. 1313-1318, 2002.

[8] C. Fang, K. Lundgren, M. Plos, and K. Gylltoft, "Bond behaviour of corroded reinforcing steel bars in concrete," Cement and Concrete Research, vol. 36, no. 10, pp. 1931-1938, 2006.

[9] L. Berto, P. Simioni, and A. Saetta, "Numerical modelling of bond behaviour in RC structures affected by reinforcement corrosion," Engineering Structures, vol. 30, no. 5, pp. 1375-1385, 2008.

[10] A. R. L. Kivell, "Effects of bond deterioration due to corrosion on seismic performance of reinforced concrete structures," 2012.

[11] U. Angst, B. Elsener, C. K. Larsen, and Ø. Vennesland, "Critical chloride content in reinforced concrete-a review," Cement and Concrete Research, vol. 39, no. 12, pp. 1122-1138, 2009. 
[12] S. E. Hussain, A. S. Al-Gahtani, and Rasheeduzzafar, "Chloride threshold for corrosion of reinforcement in concrete," ACI Materials Journal, vol. 93, no. 6, pp. 534-538, 1996.

[13] K. Y. Ann and H.-W. Song, "Chloride threshold level for corrosion of steel in concrete," Corrosion Science, vol. 49, no. 11, pp. 4113-4133, 2007.

[14] C. Alonso, C. Andrade, M. Castellote, and P. Castro, "Chloride threshold values to depassivate reinforcing bars embedded in a standardized OPC mortar," Cement and Concrete Research, vol. 30, no. 7, pp. 1047-1055, 2000.

[15] G. K. Glass and N. R. Buenfeld, "The influence of chloride binding on the chloride induced corrosion risk in reinforced concrete," Corrosion Science, vol. 42, no. 2, pp. 329-344, 2000.

[16] T. Maruya, K. Hsu, H. Takeda, and S. Tangtermsirikul, "Numerical modeling of steel corrosion in concrete structures due to chloride ion, oxygen and water movement," Journal of Advanced Concrete Technology, vol. 1, no. 2, pp. 147-160, 2003.

[17] R. B. Polder, "Critical chloride content for reinforced concrete and its relationship to concrete resistivity," Materials and Corrosion, vol. 60, no. 8, pp. 623-630, 2009.

[18] U. Angst, A. Rønnquist, B. Elsener, C. K. Larsen, and Ø. Vennesland, "Probabilistic considerations on the effect of specimen size on the critical chloride content in reinforced concrete," Corrosion Science, vol. 53, no. 1, pp. 177-187, 2011.

[19] C. Andrade, I. R. Maribona, S. Feliu, J. A. González, and S. Feliu Jr., "The effect of macrocells between active and passive areas of steel reinforcements," Corrosion Science, vol. 33, no. 2, pp. 237249, 1992.

[20] M. Raupach, "Chloride-induced macrocell corrosion of steel in concrete-theoretical background and practical consequences," Construction and Building Materials, vol. 10, no. 5, pp. 329-338, 1996.

[21] M. Raupach, Corrosion of Reinforcement in Concrete: Mechanisms, Monitoring, Inhibitors and Rehabilitation Techniques, Woodhead, Cambridge, UK, 2007.

[22] J. Warkus and M. Raupach, "Numerical modelling of macrocells occurring during corrosion of steel in concrete," Materials and Corrosion, vol. 59, no. 2, pp. 122-130, 2008.

[23] J. Warkus and M. Raupach, "Modelling of reinforcement corrosion-geometrical effects on macrocell corrosion," Materials and Corrosion, vol. 61, no. 6, pp. 494-504, 2010.

[24] K. Tuutti, Corrosion of Steel in Concrete, Swedish Cement and Concrete Research Institute, Stockholm, Sweden, 1982.

[25] P. C. Pistorius and G. T. Burstein, "Metastable pitting corrosion of stainless steel and the transition to stability," Philosophical Transactions of the Royal Society A: Mathematical, Physical and Engineering Sciences, vol. 341, no. 1662, pp. 531-559, 1992.

[26] G. T. Burstein, P. C. Pistorius, and S. P. Mattin, "The nucleation and growth of corrosion pits on stainless steel," Corrosion Science, vol. 35, no. 1-4, pp. 57-62, 1993.

[27] N. J. Laycock and R. C. Newman, "Localised dissolution kinetics, salt films and pitting potentials," Corrosion Science, vol. 39, no. 10-11, pp. 1771-1790, 1997.

[28] L. Bertolini, B. Elsener, P. Pedeferri, and R. Polder, Corrosion of Steel in Concrete: Prevention Diagnosis Repair, Wiley-VCH, Weinheim, Germany, 2004.

[29] J. P. Broomfield, Corrosion of Steel in Concrete: Understanding, Investigation and Repair, Taylor \& Francis, 2002.

[30] U. Angst, B. Elsener, C. K. Larsen, and Ø. Vennesland, "Chloride induced reinforcement corrosion: rate limiting step of early pitting corrosion," Electrochimica Acta, vol. 56, no. 17, pp. 58775889, 2011.
[31] A. A. Torres-Acosta and M. Martínez-Madrid, "Residual life of corroding reinforced concrete structures in marine environment," Journal of Materials in Civil Engineering, vol. 15, no. 4, pp. 344-353, 2003.

[32] M. G. Stewart, "Mechanical behaviour of pitting corrosion of flexural and shear reinforcement and its effect on structural reliability of corroding RC beams," Structural Safety, vol. 31, no. 1, pp. 19-30, 2009.

[33] D. V. Val and R. E. Melchers, "Reliability of deteriorating RC slab bridges," Journal of Structural Engineering, vol. 123, no. 12, pp. 1638-1644, 1997.

[34] O. B. Isgor and A. G. Razaqpur, "Predicting the initiation and propagation of corrosion in reinforced concrete structures," in Proceedings of the 4th Structural Specialty Conference of Canadian Society for Civil Engineering, Montreal, Canada, June 2002.

[35] C. Alonso, C. Andrade, and J. A. González, "Relation between resistivity and corrosion rate of reinforcements in carbonated mortar made with several cement types," Cement and Concrete Research, vol. 18, no. 5, pp. 687-698, 1988.

[36] W. López and J. A. González, "Influence of the degree of pore saturation on the resistivity of concrete and the corrosion rate of steel reinforcement," Cement and Concrete Research, vol. 23, no. 2, pp. 368-376, 1993.

[37] G. Balabanić, N. Bićanić, and A. Dureković, "Mathematical modeling of electrochemical steel corrosion in concrete," Journal of Engineering Mechanics, vol. 122, no. 12, pp. 1113-1122, 1996.

[38] G. Balabanić, N. Bićanić, and A. Đureković, "The influence of w/c ratio, concrete cover thickness and degree of water saturation on the corrosion rate of reinforcing steel in concrete," Cement and Concrete Research, vol. 26, no. 5, pp. 761-769, 1996.

[39] M. J. Katwan, T. Hodgkiess, and P. D. Arthur, "Electrochemical noise technique for the prediction of corrosion rate of steel in concrete," Materials and Structures, vol. 29, no. 5, pp. 286-294, 1996.

[40] H. Yalçyn and M. Ergun, "The prediction of corrosion rates of reinforcing steels in concrete," Cement and Concrete Research, vol. 26, no. 10, pp. 1593-1599, 1996.

[41] S. C. Kranc and A. A. Sagüés, "Modeling the time-dependent response to external polarization of a corrosion macrocell on steel in concrete," Journal of the Electrochemical Society, vol. 144, no. 8, pp. 2643-2652, 1997.

[42] C. Alonso, C. Andrade, X. R. Nóvoa, M. Izquierdo, and M. C. Pérez, "Effect of protective oxide scales in the macrogalvanic behaviour of concrete reinforcements," Corrosion Science, vol. 40, no. 8, pp. 1379-1389, 1998.

[43] C. Alonso, C. Andrade, J. Rodriguez, and J. M. Diez, "Factors controlling cracking of concrete affected by reinforcement corrosion," Materials and Structures, vol. 31, no. 211, pp. 435-441, 1996.

[44] T. Liu and R. W. Weyers, "Modeling the dynamic corrosion process in chloride contaminated concrete structures," Cement and Concrete Research, vol. 28, no. 3, pp. 365-379, 1998.

[45] M. Raupach and J. Gulikers, "A simplified method to estimate corrosion rates-a new approach based on investigations of macrocells," in Durability of Building Materials and Components 8: Service Life and Durability of Materials and Components, vol. 1, chapter 36, p. 376, 1999.

[46] K. Takewaka, T. Yamaguchi, and S. Maeda, "Simulation model for deterioration of concrete structures due to chloride attack," Journal of Advanced Concrete Technology, vol. 1, no. 2, pp. 139146, 2003. 
[47] J. Gulikers, “Theoretical considerations on the supposed linear relationship between concrete resistivity and corrosion rate of steel reinforcement," Materials and Corrosion, vol. 56, no. 6, pp. 393-403, 2005.

[48] B. Huet, V. L'hostis, G. Santarini, D. Feron, and H. Idrissi, "Steel corrosion in concrete: determinist modeling of cathodic reaction as a function of water saturation degree," Corrosion Science, vol. 49, no. 4, pp. 1918-1932, 2007.

[49] A. Scott and M. G. Alexander, "The influence of binder type, cracking and cover on corrosion rates of steel in chloridecontaminated concrete," Magazine of Concrete Research, vol. 59, no. 7, pp. 495-505, 2007.

[50] I. Martínez and C. Andrade, "Examples of reinforcement corrosion monitoring by embedded sensors in concrete structures," Cement and Concrete Composites, vol. 31, no. 8, pp. 545-554, 2009.

[51] M. Otieno, H. Beushausen, and M. Alexander, "Prediction of corrosion rate in RC structures-a critical review," in Modelling of Corroding Concrete Structures, C. Andrade and G. Mancini, Eds., vol. 5 of RILEM Bookseries, Springer, Berlin, Germany, 2011.

[52] M. Otieno, H. Beushausen, and M. Alexander, "Prediction of corrosion rate in reinforced concrete structures-a critical review and preliminary results," Materials and Corrosion, vol. 63, no. 9, pp. 777-790, 2012.

[53] ASTM, Standard Test Method for Half-Cell Potentials of Uncoated Reinforcing Steel in Concrete, ASTM C876-91, ASTM, West Conshohocken, Pa, USA, 1999.

[54] B. Elsener, C. Andrade, J. Gulikers, R. Polder, and M. Raupach, "Hall-cell potential measurements-potential mapping on reinforced concrete structures," Materials and Structures, vol. 36, no. 261, pp. 461-471, 2003.

[55] M.-T. Liang, L.-H. Lin, and C.-H. Liang, "Service life prediction of existing reinforced concrete bridges exposed to chloride environment," Journal of Infrastructure Systems, vol. 8, no. 3, pp. 76-85, 2002.

[56] Y. Zhao, H. Ren, H. Dai, and W. Jin, "Composition and expansion coefficient of rust based on X-ray diffraction and thermal analysis," Corrosion Science, vol. 53, no. 5, pp. 16461658, 2011.

[57] S. Caré, Q. T. Nguyen, V. L'Hostis, and Y. Berthaud, "Mechanical properties of the rust layer induced by impressed current method in reinforced mortar," Cement and Concrete Research, vol. 38, no. 8-9, pp. 1079-1091, 2008.

[58] C. Andrade, C. Alonso, and F. J. Molina, "Cover cracking as a function of bar corrosion: part I-experimental test," Materials and Structures, vol. 26, no. 8, pp. 453-464, 1993.

[59] C. Andrade, A. Muñoz, and A. Torres-Acosta, "Relation between crack width and corrosion degree in corroding elements exposed to the natural atmosphere," in Proceedings of 7 th International Conference on Fracture Mechanics of Concrete and Concrete Structures (FraMCoS '07), May 2010.

[60] Y. G. Du, L. A. Clark, and A. H. C. Chan, "Residual capacity of corroded reinforcing bars," Magazine of Concrete Research, vol. 57, no. 3, pp. 135-147, 2005.

[61] W. H. Peter, R. A. Buchanan, C. T. Liu et al., "Localized corrosion behavior of a zirconium-based bulk metallic glass relative to its crystalline state," Intermetallics, vol. 10, no. 11-12, pp. 1157-1162, 2002.
[62] Y. Liu, Modeling the Time-to-Corrosion Cracking of the Cover Concrete in Chloride Contaminated Reinforced Concrete Structures, Virginia Polytechnic Institute and State University, Blacksburg, Va, USA, 1996.

[63] Y. Liu and R. E. Weyers, "Modeling the time-to-corrosion cracking in chloride contaminated reinforced concrete structures," ACI Materials Journal, vol. 95, no. 6, pp. 675-681, 1998.

[64] S. J. Pantazopoulou and K. D. Papoulia, "Modeling covercracking due to reinforcement corrosion in RC structures," Journal of Engineering Mechanics, vol. 127, no. 4, pp. 342-351, 2001.

[65] K. Bhargava, A. K. Ghosh, Y. Mori, and S. Ramanujam, "Modeling of time to corrosion-induced cover cracking in reinforced concrete structures," Cement and Concrete Research, vol. 35, no. 11, pp. 2203-2218, 2005.

[66] K. Bhargava, A. K. Ghosh, Y. Mori, and S. Ramanujam, "Analytical model for time to cover cracking in RC structures due to rebar corrosion," Nuclear Engineering and Design, vol. 236, no. 11, pp. 1123-1139, 2006.

[67] T. El Maaddawy and K. Soudki, "A model for prediction of time from corrosion initiation to corrosion cracking," Cement and Concrete Composites, vol. 29, no. 3, pp. 168-175, 2007.

[68] H.-S. Lee and Y.-S. Cho, "Evaluation of the mechanical properties of steel reinforcement embedded in concrete specimen as a function of the degree of reinforcement corrosion," International Journal of Fracture, vol. 157, no. 1-2, pp. 81-88, 2009.

[69] C. A. Apostolopoulos and M. P. Papadopoulos, "Tensile and low cycle fatigue behavior of corroded reinforcing steel bars S400," Construction and Building Materials, vol. 21, no. 4, pp. 855-864, 2007.

[70] C. A. Apostolopoulos and V. P. Pasialis, "Effects of corrosion and ribs on low cycle fatigue behavior of reinforcing steel bars S400," Journal of Materials Engineering and Performance, vol. 19, no. 3, pp. 385-394, 2010.

[71] R. A. Hawileh, J. A. Abdalla, A. Al Tamimi, K. Abdelrahman, and F. Oudah, "Behavior of corroded steel reinforcing bars under monotonic and cyclic loadings," Mechanics of Advanced Materials and Structures, vol. 18, no. 3, pp. 218-224, 2011.

[72] W. Zhang, X. Song, X. Gu, and S. Li, “Tensile and fatigue behavior of corroded rebars," Construction and Building Materials, vol. 34, pp. 409-417, 2012.

[73] J. A. González, C. Andrade, C. Alonso, and S. Feliu, "Comparison of rates of general corrosion and maximum pitting penetration on concrete embedded steel reinforcement," Cement and Concrete Research, vol. 25, no. 2, pp. 257-264, 1995.

[74] J. Rodriguez, L. Ortega, and J. Casal, "Load bearing capacity of concrete columns with corroded reinforcement," in Proceedings of 4th International Symposium, Special Publication No 183, Corrosion of Reinforcement in Concrete Construction, Cambridge, UK, July 1996.

[75] J. Rodriguez, L. M. Ortega, and J. Casal, "Load carrying capacity of concrete structures with corroded reinforcement," Construction and Building Materials, vol. 11, no. 4, pp. 239-248, 1997.

[76] M. G. Stewart, "Spatial variability of pitting corrosion and its influence on structural fragility and reliability of RC beams in flexure," Structural Safety, vol. 26, no. 4, pp. 453-470, 2004.

[77] J. Cairns, G. A. Plizzari, Y. Du, D. W. Law, and C. Franzoni, "Mechanical properties of corrosion-damaged reinforcement," ACI Materials Journal, vol. 102, no. 4, Article ID 102-M29, pp. 256-264, 2005. 
[78] A. A. Torres-Acosta, S. Navarro-Gutierrez, and J. Terán-Guillén, "Residual flexure capacity of corroded reinforced concrete beams," Engineering Structures, vol. 29, no. 6, pp. 1145-1152, 2007.

[79] M. G. Stewart and A. Al-Harthy, "Pitting corrosion and structural reliability of corroding RC structures: experimental data and probabilistic analysis," Reliability Engineering and System Safety, vol. 93, no. 3, pp. 373-382, 2008.

[80] T. D. Marcotte, Characterization of chloride-induced corrosion products that form in steel-reinforced cementitious materials [Ph.D. thesis], University of Waterloo, Waterloo, Canada, 2001.

[81] M. Raupach, G. Weizhong, and J. Wei-Liang, "Korrosionsprodukte und deren Volumenfaktor bei der Korrosion von Stahl in Beton," Beton- und Stahlbetonbau, vol. 105, no. 9, pp. 572-578, 2010.

[82] G. J. Al-Sulaimani, M. Kaleemullah, I. A. Basunbul, and Rasheeduzzafar, "Influence of corrosion and cracking on bond behavior and strength of reinforced concrete members," ACI Structural Journal, vol. 87, no. 2, pp. 220-231, 1990.

[83] Y. Tachibana, K.-I. Maeda, Y. Kajikawa, and M. Kawamura, Mechanical Behaviour of RC Beams Damaged by Corrosion of Reinforcement, Elsevier Applied Science, 1990.

[84] J. G. Cabrera, "Deterioration of concrete due to reinforcement steel corrosion," Cement and Concrete Composites, vol. 18, no. 1, pp. 47-59, 1996.

[85] A. A. Almusallam, A. S. Al Gahtani, A. S. A. Gahtani, M. Maslehuddin, M. M. Khan, and A. R. Aziz, "Evaluation of repair materials for functional improvement of slabs and beams with corroded reinforcement," Proceedings of the Institution of Civil Engineers-Structures and Buildings, vol. 122, no. 1, pp. 27-34, 1997.

[86] R. Huang and C. C. Yang, "Condition assessment of reinforced concrete beams relative to reinforcement corrosion," Cement and Concrete Composites, vol. 19, no. 2, pp. 131-137, 1997.

[87] L. Amleh and S. Mirza, "Corrosion influence on bond between steel and concrete," ACI Structural Journal, vol. 96, no. 3, pp. 415-423, 1999.

[88] P. S. Mangat and M. S. Elgarf, "Flexural strength of concrete beams with corroding reinforcement," ACI Structural Journal, vol. 96, no. 1, pp. 149-158, 1999.

[89] P. S. Mangat and M. S. Elgarf, "Strength and serviceability of repaired reinforced concrete beams undergoing reinforcement corrosion," Magazine of Concrete Research, vol. 51, no. 2, pp. 97112, 1999.

[90] T. A. El Maaddawy and K. A. Soudki, "Effectiveness of impressed current technique to simulate corrosion of steel reinforcement in concrete," Journal of Materials in Civil Engineering, vol. 15, no. 1, pp. 41-47, 2003.

[91] T. Vidal, A. Castel, and R. François, "Analyzing crack width to predict corrosion in reinforced concrete," Cement and Concrete Research, vol. 34, no. 1, pp. 165-174, 2004.

[92] K. Vu, M. G. Stewart, and J. Mullard, "Corrosion-induced cracking: experimental data and predictive models," ACI Structural Journal, vol. 102, no. 5, pp. 719-726, 2005.

[93] J. Zhong, P. Gardoni, and D. Rosowsky, "Seismic fragility estimates for corroding reinforced concrete bridges," Structure and Infrastructure Engineering, vol. 8, no. 1, pp. 55-69, 2012.

[94] R. Zhang, A. Castel, and R. François, "Concrete cracking due to chloride-induced reinforcement corrosion-influence of steelconcrete interface defects due to the 'top-bar effect"' European Journal of Environmental and Civil Engineering, vol. 16, no. 3-4, pp. 402-413, 2012.
[95] M. Maslehuddin, I. M. Allam, G. J. Al-Sulaimani, A. Al-Mana, and S. N. Abduljauwad, "Effect of rusting of reinforcing steel on its mechanical properties and bond with concrete," ACI Materials Journal, vol. 87, no. 5, pp. 496-502, 1990.

[96] C. Andrade, C. Alonso, D. Garcia, and J. Rodriguez, "Remaining lifetime of reinforced concrete structures: effect of corrosion in the mechanical properties of the steel, life predication of corrodible structures," in Proceedings of the NACE, pp. 12/112/11, Cambridge, UK, September 1991.

[97] I. M. Allam, M. Maslehuddin, H. Saricimen, and A. I. Al-Mana, "Influence of atmospheric corrosion on the mechanical properties of reinforcing steel," Construction and Building Materials, vol. 8, no. 1, pp. 35-41, 1994.

[98] M. Saifullah, Effect of reinforcement corrosion on bond strength in reinforced concrete [Ph.D. thesis], The University of Birmingham, Birmingham, UK, 1994.

[99] P. S. Zhang, M. Lu, and X. Y. Li, "The mechanical behavior of corroded bar," Journal of Industrial Buildings, vol. 25, no. 257, pp. 41-44, 1995.

[100] S. Morinaga, "Remaining life of reinforced concrete structures after corrosion cracking," Durability of Building Materials and Components, vol. 71, pp. 127-136, 1996.

[101] H. Lee, F. Tomosawa, and T. Noguchi, "Effects of rebar corrosion on the structural performance of singly reinforced beams," Durability of Building Materials and Components, vol. 7, pp. 571580, 1996.

[102] A. Castel, R. François, and G. Arliguie, "Mechanical behaviour of corroded reinforced concrete beams-part 1: experimental study of corroded beams," Materials and Structures, vol. 33, no. 9, pp. 539-544, 2000.

[103] Y. G. Du, Effect of reinforcement corrosion on structural concrete ductility [Ph.D. thesis], The University of Birmingham, Birmingham, UK, 2001.

[104] A. A. Almusallam, "Effect of degree of corrosion on the properties of reinforcing steel bars," Construction and Building Materials, vol. 15, no. 8, pp. 361-368, 2001.

[105] R. Palsson and M. S. Mirza, "Mechanical response of corroded steel reinforcement of abandoned concrete bridge," ACI Structural Journal, vol. 99, no. 2, pp. 157-162, 2002.

[106] M. Oyado, T. Kanakubo, T. Sato, and Y. Yamamoto, "Bending performance of reinforced concrete member deteriorated by corrosion," Structure and Infrastructure Engineering, vol. 7, no. 1-2, pp. 121-130, 2011.

[107] A. A. Almusallam, A. S. Al-Gahtani, A. R. Aziz, and Rasheeduzzafar, "Effect of reinforcement corrosion on bond strength," Construction and Building Materials, vol. 10, no. 2, pp. 123-129, 1996.

[108] X. Fu and D. D. L. Chung, "Effect of corrosion on the bond between concrete and steel rebar," Cement and Concrete Research, vol. 27, no. 12, pp. 1811-1815, 1997.

[109] K. Soudki and T. Sherwood, "Bond behavior of corroded steel reinforcement in concrete wrapped with carbon fiber reinforced polymer sheets," Journal of Materials in Civil Engineering, vol. 15, no. 4, pp. 358-370, 2003.

[110] L. Chung, S.-H. Cho, J.-H. J. Kim, and S.-T. Yi, "Correction factor suggestion for ACI development length provisions based on flexural testing of RC slabs with various levels of corroded reinforcing bars," Engineering Structures, vol. 26, no. 8, pp. 10131026, 2004

[111] C. Fang, K. Lundgren, L. Chen, and C. Zhu, "Corrosion influence on bond in reinforced concrete," Cement and Concrete Research, vol. 34, no. 11, pp. 2159-2167, 2004. 
[112] A. Ouglova, Y. Berthaud, F. Foct, M. François, F. Ragueneau, and I. Petre-Lazar, "The influence of corrosion on bond properties between concrete and reinforcement in concrete structures," Materials and Structures, vol. 41, no. 5, pp. 969-980, 2008.

[113] L. Chung, J.-H. Jay Kim, and S.-T. Yi, "Bond strength prediction for reinforced concrete members with highly corroded reinforcing bars," Cement and Concrete Composites, vol. 30, no. 7, pp. 603-611, 2008.

[114] C. Fang, K. Gylltoft, K. Lundgren, and M. Plos, "Effect of corrosion on bond in reinforced concrete under cyclic loading," Cement and Concrete Research, vol. 36, no. 3, pp. 548-555, 2006.

[115] J. B. Mander, M. J. Priestley, and R. Park, "Theoretical stressstrain model for confined concrete," Journal of Structural Engineering, vol. 114, no. 8, pp. 1804-1826, 1988.

[116] Y.-C. Ou, H.-D. Fan, and N. D. Nguyen, "Long-term seismic performance of reinforced concrete bridges under steel reinforcement corrosion due to chloride attack," Earthquake Engineering \& Structural Dynamics, vol. 42, no. 14, pp. 21132127, 2013.

[117] F. J. Vecchio and M. P. Collins, “The modified compression-field theory for reinforced concrete elements subjected to shear," ACI Structural Journal, vol. 83, no. 2, pp. 219-231, 1986.

[118] F. J. Vecchio and M. P. Collins, "Compression response of cracked reinforced concrete," Journal of Structural Engineering, vol. 119, no. 12, pp. 3590-3610, 1993.

[119] M. Capé, Residual service-life assessment of existing R/C structures [M.S. thesis], Chalmers University of Technology, Gothenburg, Sweden; Milan University of Technology, Milan, Italy, 1999.

[120] P. Mehta, "Concrete Technology at the Crossroad-Problem and Opportunities," in Conerete Technology: Past, Present and Future, ACI SP144-1, American Concrete Institute, 1994.

[121] P. A. M. Basheer, S. E. Chidiac, and A. E. Long, "Predictive models for deterioration of concrete structures," Construction and Building Materials, vol. 10, no. 1, pp. 27-37, 1996.

[122] P. Thoft-Christensen, F. Jensen, C. Middleton, and A. Blackmore, Assessment of the Reliability of Concrete Slab Bridges, Department of Building Technology and Structural Engineering, 1996.

[123] D. V. Val, M. G. Stewart, and R. E. Melchers, "Effect of reinforcement corrosion on reliability of highway bridges," Engineering Structures, vol. 20, no. 11, pp. 1010-1019, 1998.

[124] D.-E. Choe, P. Gardoni, D. Rosowsky, and T. Haukaas, "Probabilistic capacity models and seismic fragility estimates for RC columns subject to corrosion," Reliability Engineering \& System Safety, vol. 93, no. 3, pp. 383-393, 2008.

[125] Z. P. Bazant, "Physical model for steel corrosion in concrete sea structures-theory," Journal of the Structural Division, vol. 105, no. 6, pp. 1137-1153, 1979.

[126] Z. P. Bazant, "Physical model for steel corrosion in concrete sea structures-application," Journal of the Structural Division, vol. 105, pp. 1155-1166, 1979, ASCE 14652 Proceeding.

[127] J. De Brito and F. Branco, "Whole life costing in road bridges applied to service life prediction," in Proceedings of the $3 \mathrm{rd}$ International Conference on Bridge Management, Bridge Management 3. Inspection, Maintenance and Repair, pp. 603-612, University of Surrey, Guildford, UK, April 1996.

[128] S. Ng and F. Moses, "Prediction of bridge service life using timedependent reliability analysis," Bridge Management, vol. 3, pp. 26-32, 1996.
[129] M. P. Enright and D. M. Frangopol, "Service-life prediction of deteriorating concrete bridges," Journal of Structural Engineering, vol. 124, no. 3, pp. 309-317, 1998.

[130] F. Biondini and D. M. Frangopol, "Probabilistic limit analysis and lifetime prediction of concrete structures," Structure and Infrastructure Engineering, vol. 4, no. 5, pp. 399-412, 2008.

[131] J. B. Mander and N. Basöz, "Seismic fragility curve theory for highway bridges," in Proceedings of the 5th US Conference on Lifeline Earthquake Engineering, Optimizing Post-Earthquake Lifeline System Reliability, ASCE, Seattle, Wash, USA, August 1999.

[132] J. Moehle, A. Lynn, K. Elwood, and H. Sezen, "Gravity load collapse of reinforced concrete frames during earthquakes," in Proceedings of the 1st US-Japan Workshop on Performance-Based Design Methodology for Reinforced Concrete Building Structures, Pacific Earthquake Engineering Research Center, University of California, 1999.

[133] M. Shinozuka, M. Q. Feng, J. Lee, and T. Naganuma, "Statistical analysis of fragility curves," Journal of Engineering Mechanics, vol. 126, no. 12, pp. 1224-1231, 2000.

[134] P. Gardoni, A. Der Kiureghian, and K. M. Mosalam, "Probabilistic capacity models and fragility estimates for reinforced concrete columns based on experimental observations," Journal of Engineering Mechanics, vol. 128, no. 10, pp. 1024-1038, 2002.

[135] K. A. Porter, "An overview of PEER's performance-based earthquake engineering methodology," in Proceedings of the on Applications of Statistics and Probability in Civil Engineering (ICASP '9), Civil Engineering Risk and Reliability Association (CERRA '03), San Francisco, Calif, USA, 2003.

[136] J. Moehle and G. G. Deierlein, "A framework methodology for performance-based earthquake engineering," in Proceedings of the 13th World Conference on Earthquake Engineering, 2004.

[137] S. Matsuki, S. Billington, and J. Baker, "Impact of long-term material degradation on seismic performance of a reinforced concrete bridge," in Proceedings of the 8th US National Conference on Earthquake Engineering, San Francisco, Calif, USA, April 2006.

[138] M. Akiyama and D. M. Frangopol, "Long-term seismic performance of RC structures in an aggressive environment: emphasis on bridge piers," Structure and Infrastructure Engineering, vol. 10, no. 7, pp. 865-879, 2014.

[139] M. S. Dietz, L. Dihoru, O. Oddbjornsson et al., "Earthquake and large structures testing at the Bristol laboratory for advanced dynamics engineering," in Role of Seismic Testing Facilities in Performance-Based Earthquake, pp. 21-41, Springer, 2012.

[140] T. Less and H. Adeli, "Computational earthquake engineering of bridges," Scientia Iranica, vol. 17, no. 5, pp. 325-338, 2010.

[141] A. Palermo and S. Pampanin, "Enhanced seismic performance of hybrid bridge systems: comparison with traditional monolithic solutions," Journal of Earthquake Engineering, vol. 12, no. 8, pp. 1267-1295, 2008.

[142] H. Lv, J. Teng, and D. Zou, "Seismic performance under environment corrosion for curved beam bridges with high piers," in Proceedings of the 2nd International Conference on Multimedia Technology (ICMT '11), pp. 1693-1696, IEEE, Hangzhou, China, July 2011.

[143] F. Biondini, E. Camnasio, and A. Palermo, "Lifetime seismic performance of concrete bridges exposed to corrosion," Structure and Infrastructure Engineering, vol. 10, no. 7, pp. 880-900, 2014. 
[144] D.-E. Choe, P. Gardoni, D. Rosowsky, and T. Haukaas, "Seismic fragility estimates for reinforced concrete bridges subject to corrosion," Structural Safety, vol. 31, no. 4, pp. 275-283, 2009.

[145] J. Ghosh and J. E. Padgett, "Aging considerations in the development of time-dependent seismic fragility curves," Journal of Structural Engineering, vol. 136, no. 12, pp. 1497-1511, 2010.

[146] J. Simon, J. M. Bracci, and P. Gardoni, "Seismic response and fragility of deteriorated reinforced concrete bridges," Journal of Structural Engineering, vol. 136, no. 10, pp. 1273-1281, 2010.

[147] P. Gardoni and D. Rosowsky, "Seismic fragility increment functions for deteriorating reinforced concrete bridges," Structure and Infrastructure Engineering, vol. 7, no. 11, pp. 869-879, 2011.

[148] H. J. Dagher and S. Kulendran, "Finite element modeling of corrosion damage in concrete structures," ACI Structural Journal, vol. 89, no. 6, pp. 699-708, 1992.

[149] R. Capozucca, "Damage to reinforced concrete due to reinforcement corrosion," Construction and Building Materials, vol. 9, no. 5, pp. 295-303, 1995.

[150] F. Biondini, F. Bontempi, D. M. Frangopol, and P. G. Malerba, "Cellular automata approach to durability analysis of concrete structures in aggressive environments," Journal of Structural Engineering, vol. 130, no. 11, pp. 1724-1737, 2004.

[151] F. Biondini, F. Bontempi, D. M. Frangopol, and P. G. Malerba, "Probabilistic service life assessment and maintenance planning of concrete structures," Journal of Structural Engineering, vol. 132, no. 5, pp. 810-825, 2006.

[152] M. Akiyama, D. M. Frangopol, and H. Matsuzaki, "Life-cycle reliability of RC bridge piers under seismic and airborne chloride hazards," Earthquake Engineering \& Structural Dynamics, vol. 40, no. 15, pp. 1671-1687, 2011.

[153] R. Kumar and P. Gardoni, "Modeling structural degradation of RC bridge columns subjected to earthquakes and their fragility estimates," Journal of Structural Engineering, vol. 138, no. 1, pp. 42-51, 2012.

[154] Y. Ma, Y. Che, and J. Gong, "Behavior of corrosion damaged circular reinforced concrete columns under cyclic loading," Construction and Building Materials, vol. 29, pp. 548-556, 2012.

[155] A. Meda, S. Mostosi, Z. Rinaldi, and P. Riva, "Experimental evaluation of the corrosion influence on the cyclic behaviour of RC columns," Engineering Structures, vol. 76, pp. 112-123, 2014.

[156] A. Palermo and M. Mashal, "Accelerated bridge construction $(\mathrm{ABC})$ and seismic damage resistant technology: a New Zealand challenge," Bulletin of the New Zealand Society for Earthquake Engineering, vol. 45, no. 3, pp. 123-134, 2012.

[157] R. E. Weyers, B. D. Prowell, M. M. Sprinkel, and M. Vorster, "Concrete bridge protection, repair, and rehabilitation relative to reinforcement corrosion: a methods application manual," Contract, vol. 100, article 103, 1993.

[158] A. M. Vaysburd and P. H. Emmons, "How to make today's repairs durable for tomorrow-corrosion protection in concrete repair," Construction and Building Materials, vol. 14, no. 4, pp. 189-197, 2000.

[159] L. Gergely, C. P. Pantelides, R. J. Nuismer, and L. D. Reaveley, "Bridge pier retrofit using fiber-reinforced plastic composites," Journal of Composites for Construction, vol. 2, no. 4, pp. 165-174, 1998.

[160] H. A. Toutanji, "Durability characteristics of concrete columns confined with advanced composite materials," Composite Structures, vol. 44, no. 2-3, pp. 155-161, 1999.

[161] M. Demers and K. W. Neale, "Confinement of reinforced concrete columns with fibre-reinforced composite sheets-an experimental study," Canadian Journal of Civil Engineering, vol. 26, no. 2, pp. 226-241, 1999.

[162] S. J. Pantazopoulou, J. F. Bonacci, S. Sheikh, M. D. A. Thomas, and N. Hearn, "Repair of corrosion-damaged columns with FRP wraps," Journal of Composites for Construction, vol. 5, no. 1, pp. 3-11, 2001.

[163] I. Baiyasi and R. Harichandran, "Corrosion and wrap strains in concrete bridge columns repaired with FRP wraps," in Proceedings of the 80th Annual Meeting of the Transportation Research Board, (CD-ROM), Washington, DC, USA, January 2001.

[164] M.-H. Teng, E. D. Sotelino, and W.-F. Chen, "Performance evaluation of reinforced concrete bridge columns wrapped with fiber reinforced polymers," Journal of Composites for Construction, vol. 7, no. 2, pp. 83-92, 2003.

[165] C. Lee, J. F. Bonacci, M. D. A. Thomas et al., "Accelerated corrosion and repair of reinforced concrete columns using carbon fibre reinforced polymer sheets," Canadian Journal of Civil Engineering, vol. 27, no. 5, pp. 941-948, 2000.

[166] E. Berver, D. Fowler, J. Jirsa, H. Wheat, and M. Ford, "Corrosion in FRP-wrapped concrete members," in Proceedings of the International Conference on Structural Faults and Repair, Engineering Technics, London, UK, 2001.

[167] G. Mullins, R. Sen, A. Torres-Acosta et al., "Lateral capacity of corroded pile bents," Final Report, University of South Florida, 2001.

[168] A. S. Debaiky, M. F. Green, and B. B. Hope, "Carbon fiberreinforced polymer wraps for corrosion control and rehabilitation of reinforced concrete columns," ACI Materials Journal, vol. 99, no. 2, pp. 129-137, 2002.

[169] R. Sen, "Advances in the application of FRP for repairing corrosion damage," Progress in Structural Engineering and Materials, vol. 5, no. 2, pp. 99-113, 2003.

[170] I. A. Wootton, L. K. Spainhour, and N. Yazdani, "Corrosion of steel reinforcement in carbon fiber-reinforced polymer wrapped concrete cylinders," Journal of Composites for Construction, vol. 7, no. 4, pp. 339-347, 2003.

[171] T. El Maaddawy, A. Chahrour, and K. Soudki, "Effect of fiberreinforced polymer wraps on corrosion activity and concrete cracking in chloride-contaminated concrete cylinders," Journal of Composites for Construction, vol. 10, no. 2, pp. 139-147, 2006.

[172] M. F. Green, L. A. Bisby, A. Z. Fam, and V. K. R. Kodur, "FRP confined concrete columns: behaviour under extreme conditions," Cement and Concrete Composites, vol. 28, no. 10, pp. 928-937, 2006.

[173] S. Gadve, A. Mukherjee, and S. N. Malhotra, "Corrosion of steel reinforcements embedded in FRP wrapped concrete," Construction and Building Materials, vol. 23, no. 1, pp. 153-161, 2009.

[174] T. E. Maaddawy, "Behavior of corrosion-damaged RC columns wrapped with FRP under combined flexural and axial loading," Cement and Concrete Composites, vol. 30, no. 6, pp. 524-534, 2008.

[175] J. Li, J. Gong, and L. Wang, "Seismic behavior of corrosiondamaged reinforced concrete columns strengthened using combined carbon fiber-reinforced polymer and steel jacket," Construction and Building Materials, vol. 23, no. 7, pp. 26532663, 2009.

[176] R. S. Aboutaha, F. Jnaid, S. Sotoud, and M. Tapan, Seismic Evaluation and Retrofit of Deteriorated Concrete Bridge Components, Project no: 49111-23-22, University of Syracuse, Syracuse, NY, USA, 2013. 
[177] A. Alipour, B. Shafei, and M. Shinozuka, "Performance evaluation of deteriorating highway bridges located in high seismic areas," Journal of Bridge Engineering, vol. 16, no. 5, pp. 597-611, 2011.

[178] D.-E. Choe, P. Gardoni, and D. Rosowsky, "Fragility increment functions for deteriorating reinforced concrete bridge columns," Journal of Engineering Mechanics, vol. 136, no. 8, pp. 969-978, 2010. 

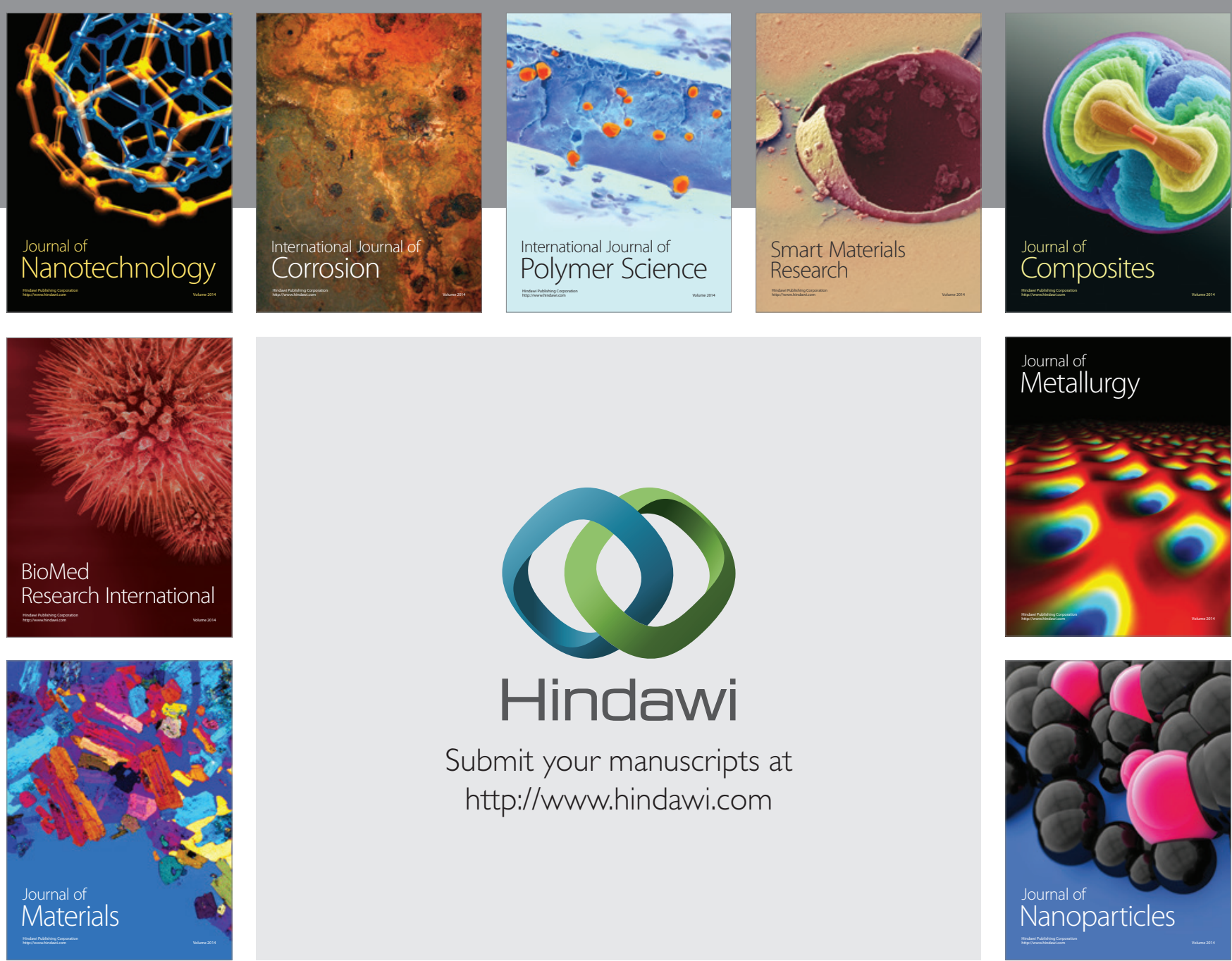

\section{Hindawi}

Submit your manuscripts at

http://www.hindawi.com

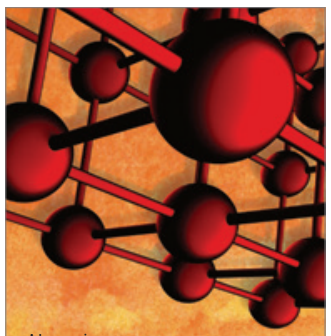

Materials Science and Engineering
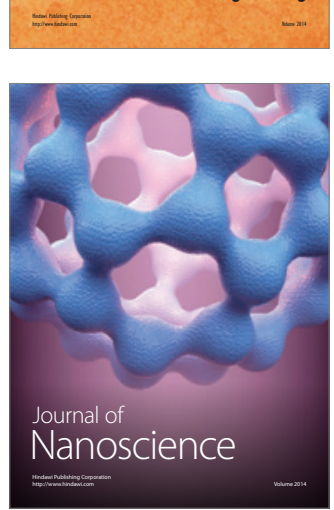
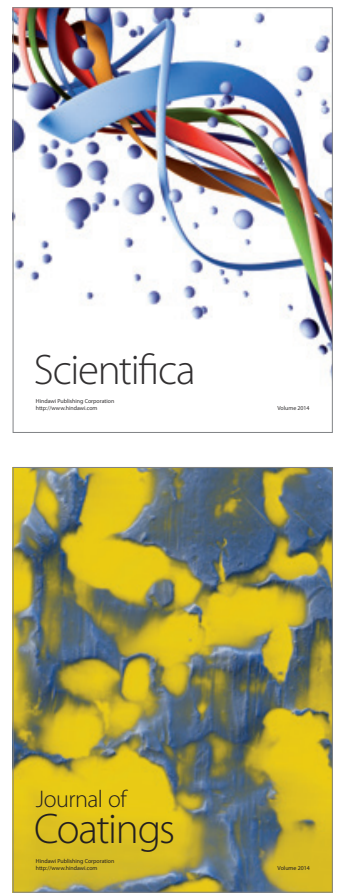
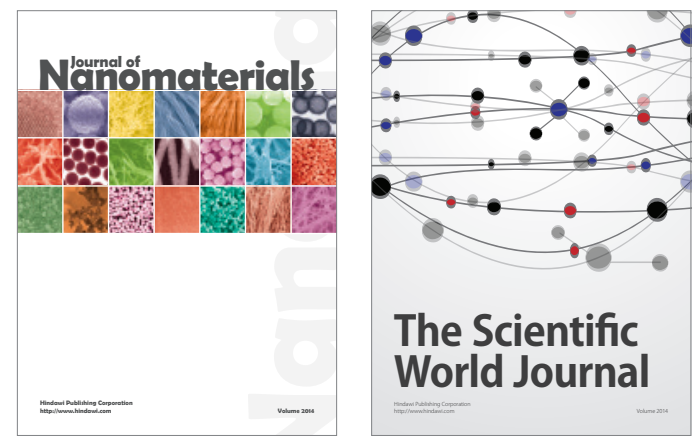

The Scientific World Journal
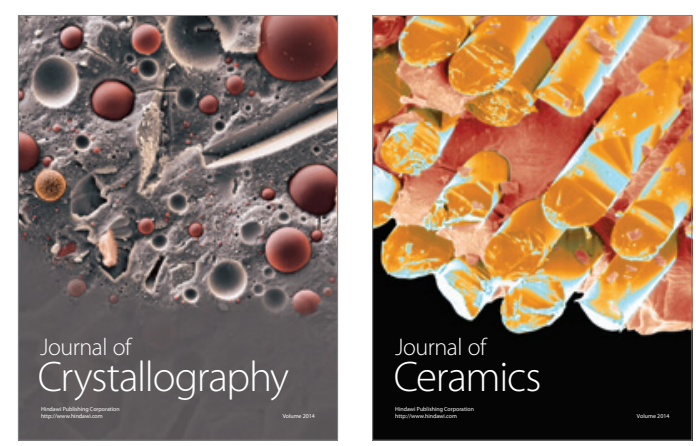
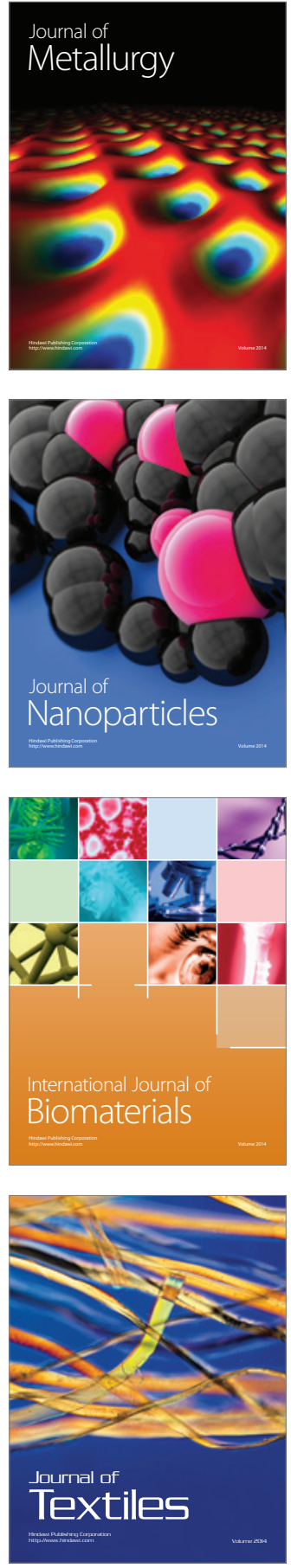